\title{
The Effect of Self-efficacy, Locus of Control, and Dark Personality Trait on Fraudulent Fiinancial Reporting
}

\author{
Farzaneh Rezazadeh \\ Ph.D. Candidate, Department of Accounting, Qazvin Branch, Islamic Azad \\ University(Brezazade@ymail.com) \\ Farzain Rezaei * \\ Associate Prof., Department of Accounting, Qazvin Branch, Islamic Azad \\ University, Qazvin, Iran (Corresponding Author), farzin.rezaei@qiau.ac.ir \\ Naser Hamidi \\ Associate Prof., Department of Management, Qazvin Branch, Islamic Azad \\ (University, Qazvin, Iran(nhamidi1344@gmail.com
}

\begin{abstract}
:
Psychological variables cause behavioral differences in managers; Therefore, these variables are known to be an influential factor in the intention of fraud in financial reporting. The present study seeks to investigate the effect of self-efficacy, Locus of control and dark personality traits on fraudulent financial reporting. Data that could be tested were collected from 352 observations among financial managers and accountants located in companies listed on the Tehran Stock Exchange, and their analysis was performed using Smart PLS3 software and structural equation modeling. The results of statistical analysis showed that dark personality traits (narcissism, Machiavellianism, anti-socialism, and sadism) have a positive and significant effect on fraudulent financial reporting, while cognitive characteristics of selfefficacy and Locus of control have no significant effect on fraudulent financial reporting. Also, based on the research findings, self-efficacy and control source have a negative and significant effect on dark personality traits. The results of this study confirm the importance of psychological components in understanding the causes of managerschr(chr('39')39chr('39')) unethical behavior that lead to fraud in financial reporting. Therefore, by understanding the psychological components that affect the performance of managers and especially the fraudulent behavior of managers, it is possible to help prevent preventive measures in this area.
\end{abstract}

Keywords: Self-efficacy, Locus of control, Tetrad of Dark Personality, Fraudulent Financial Reporting.

\section{Copyrights}

\section{(c) (1) ()}

This license only allowing others to download your works and share them with others as long as they credit you, but they can't change them in any way or use them commercial. 


\section{مقاله برؤوهى}

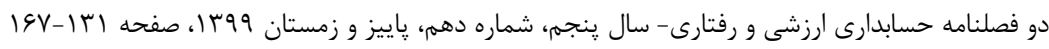

\section{تاثير خودكار آمدى، منبع كنترل و ويزّىىهاى تاريك شخصيت بر كزارشكرى مالى متقلبانه}

فرزانه رضازاده ' فرزين رضايع."r

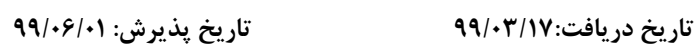

جكيده

متغيرهاى روانشناختى سبب بروز تفاوتهاى رفتارى در مديران مىشوند؛ بنابراين، اين

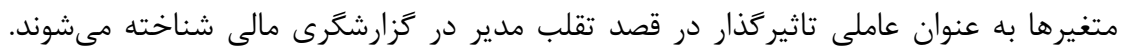

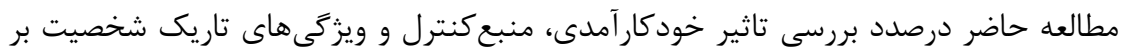

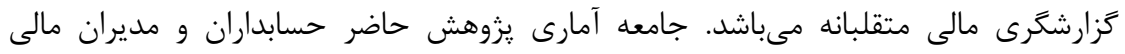

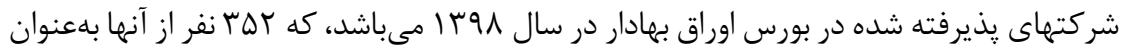

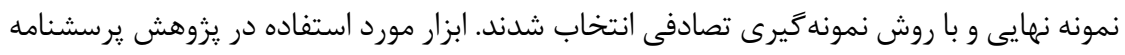

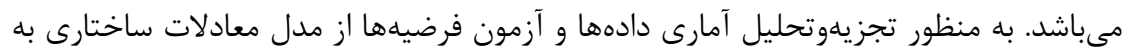

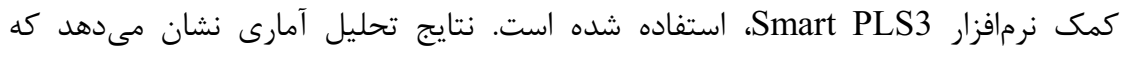

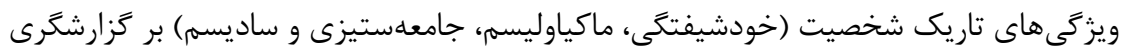

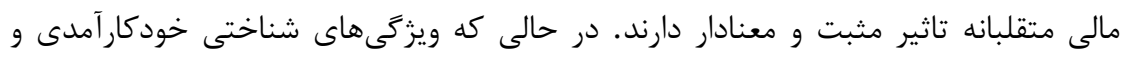

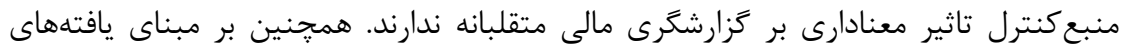

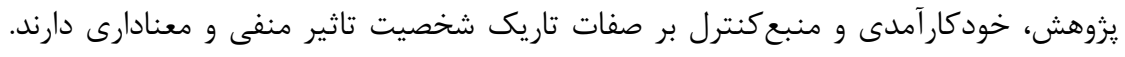

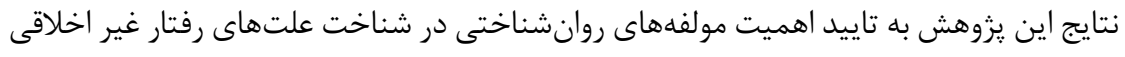

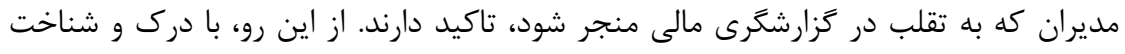

$$
\begin{aligned}
& \text { 'دانشجوى دكترى، كروه حسابدارى، واحد قزوين، دانشخاه آزاد اسلامى، قزوين، ايران } \\
& \text { 'دانشيار، گروه حسابدارى، واحد قزوين، دانشخاه آزاد اسلامى، قزوين، ايران (نويسنده مسئول)، }
\end{aligned}
$$
dr.banimahd@gmail.com كانشيار، كروه مديريت، واحد قزوين، دانشكاه آزاد اسلامى، قزوين، ايران 
مولفههاى روانشناختى تاثير كذار بر عملكرد مديران و بهويزه رفتار متقلبانه مديران، مىتوان به

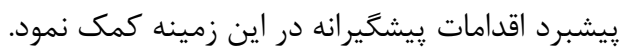

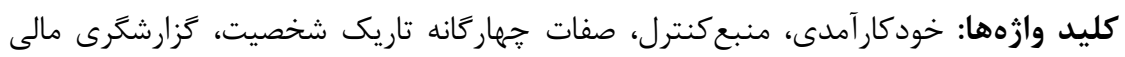

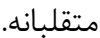


به طور عمومى، تقلب بهعنوان اقدامى ارادى براى كسب مزاياى غيرمنصفانه و غير قانونى

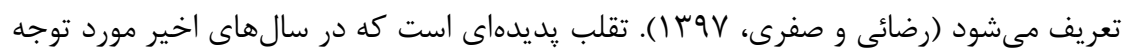
يزوهشكَران رشتههاى مختلف از جمله حسابدارى قرار گرفته است. نتايج يزوهشهائها در اين زمينه

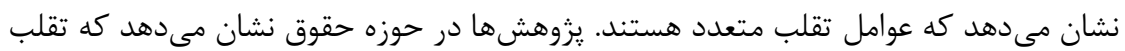

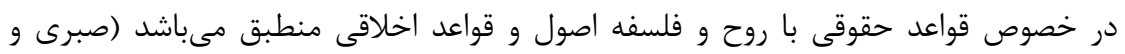

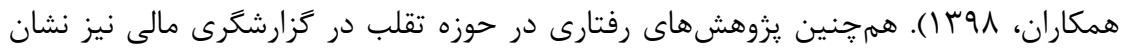

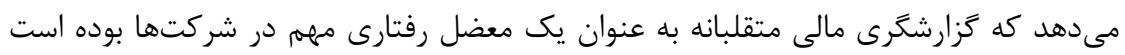

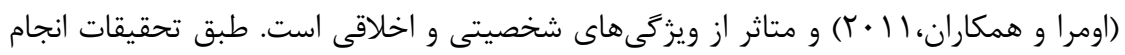
شده، ويرگى هاى تاريك شخصيت، مهمترين عامل ريسك تقلب مى باشند (كوهن و همكاران،

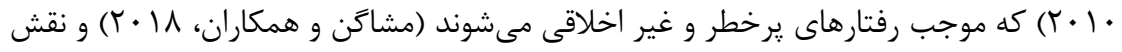

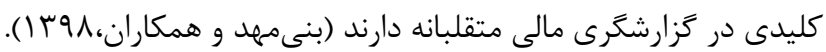

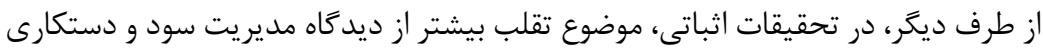

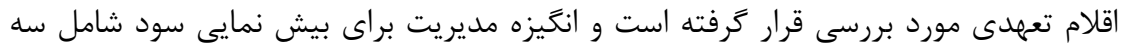

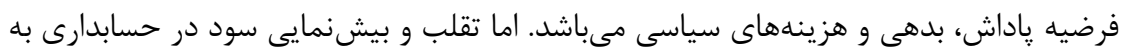

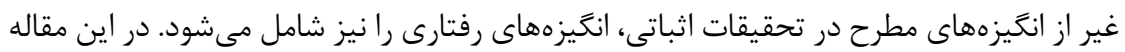

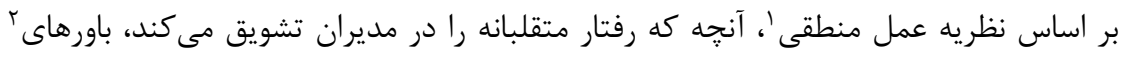

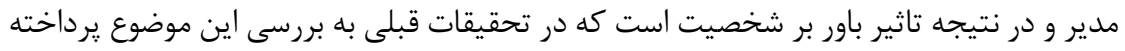

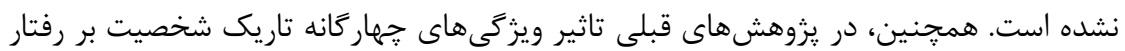

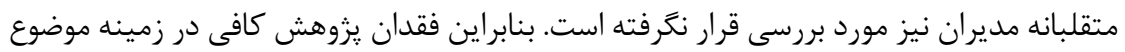

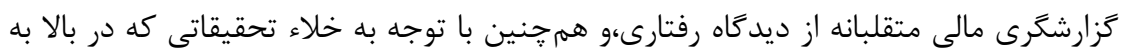

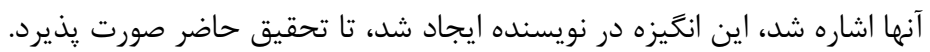

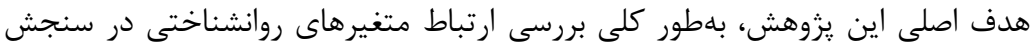

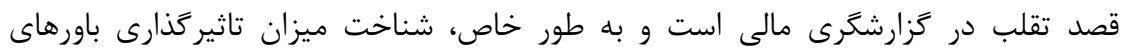

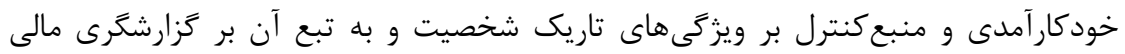

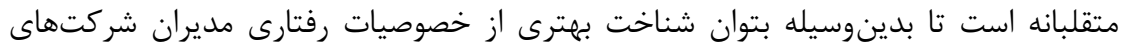

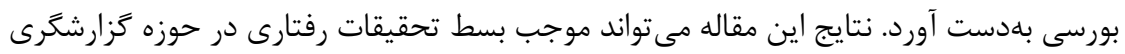

1 Theory of reasoned action

2 Belief 


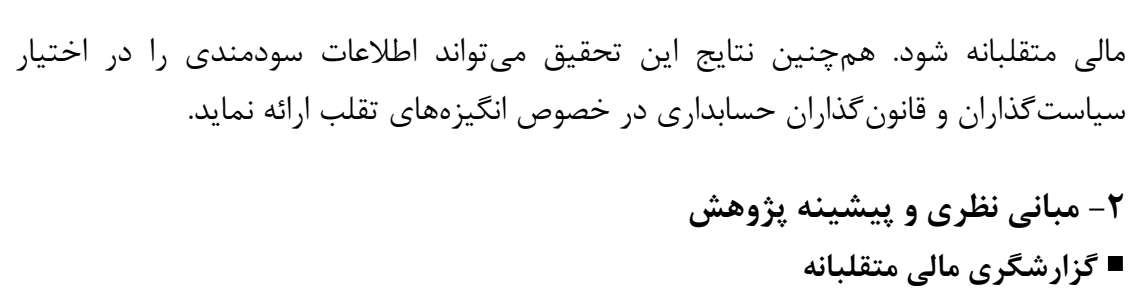

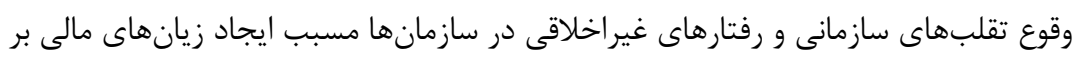

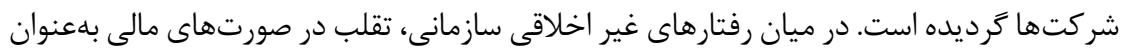

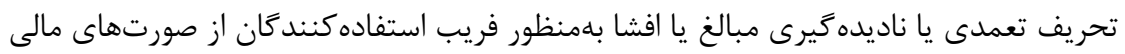

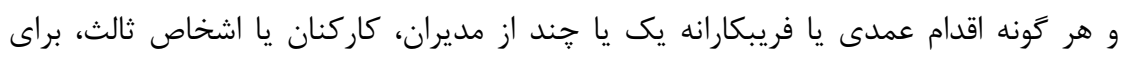

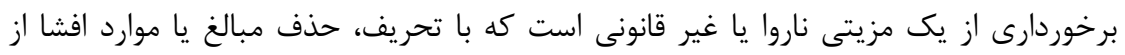

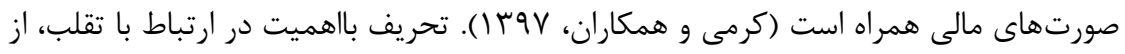

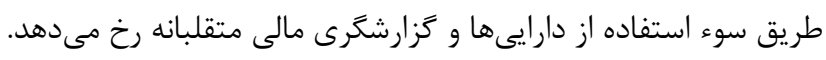

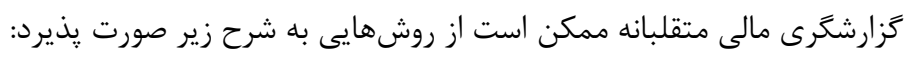

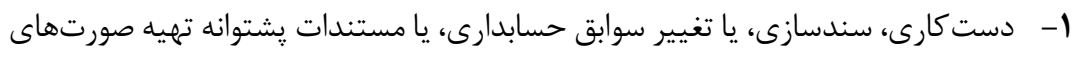
مالى يا

r- ارائه نادرست يا حذف عمدى معاملات، ساير رويدادها يا ساير اطلاعات عمده در

$$
\text { صورتهاى مالى يا }
$$

r- به كاركيرى نادرست استانداردهاى حسابدارى در رابطه با مبالغ، طبقهبندى، نحوه ارائه

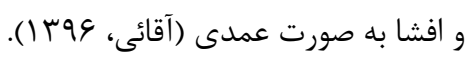

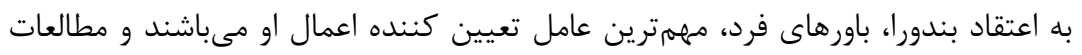

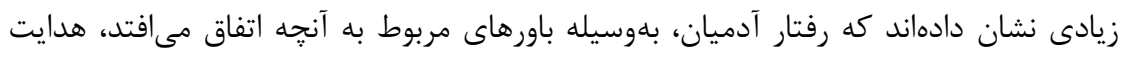

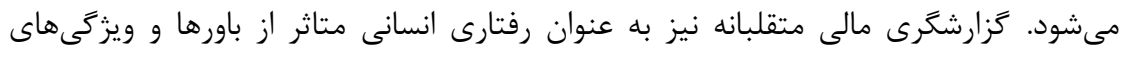

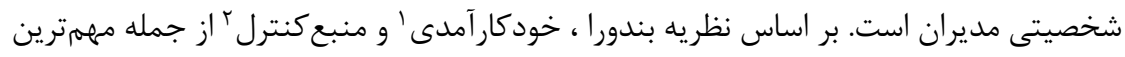

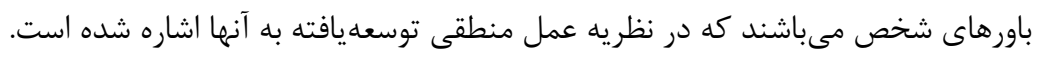

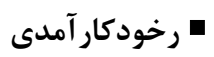

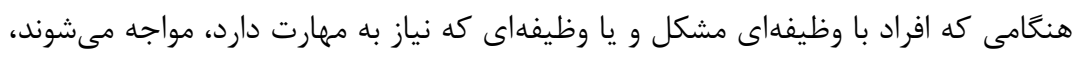

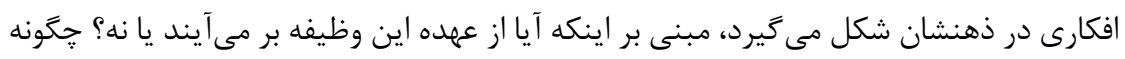

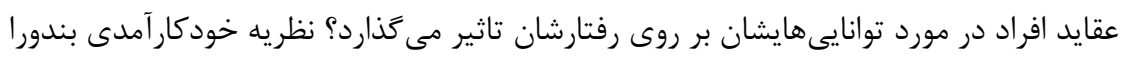

1 Self-efficacy

2 Locus of Control 


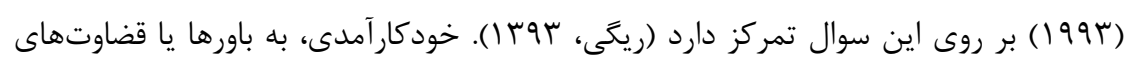

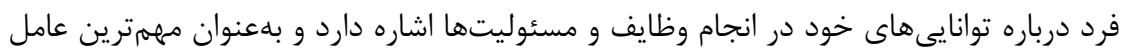

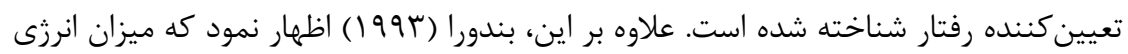

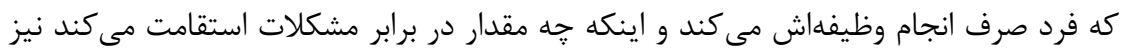

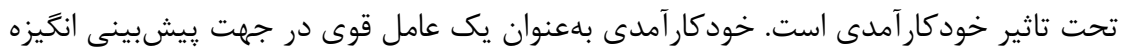

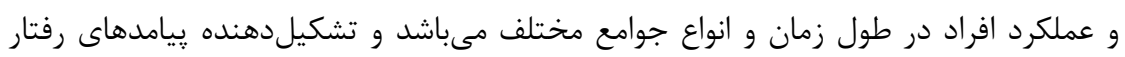

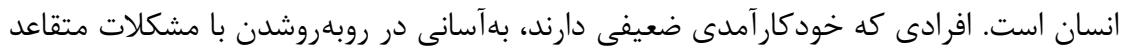

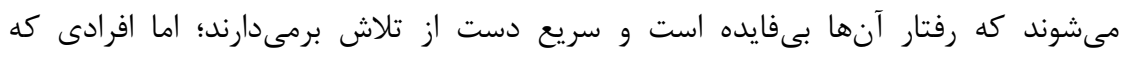

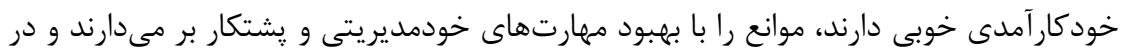

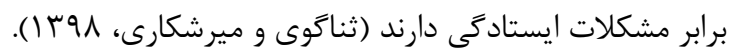

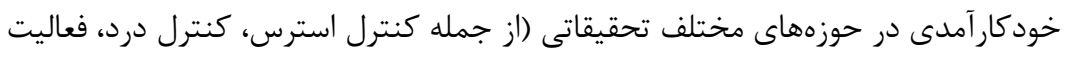

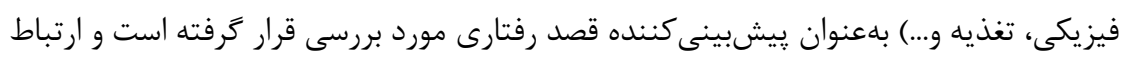

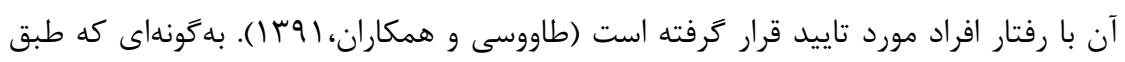

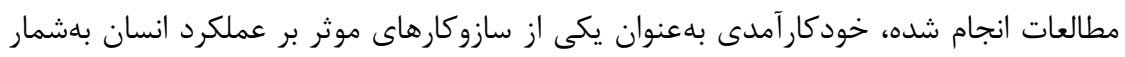

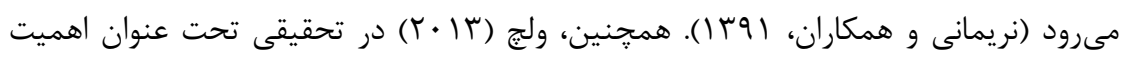

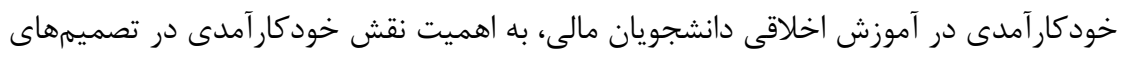

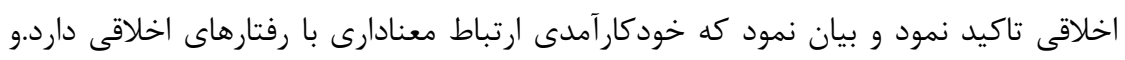

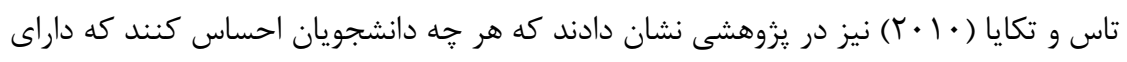

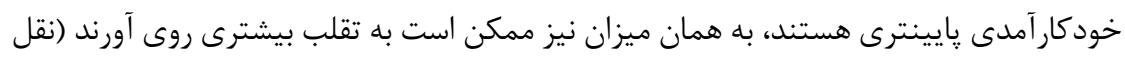

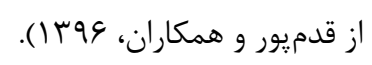
- منبع كنترل

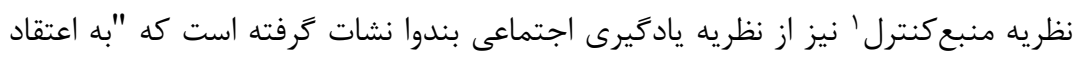

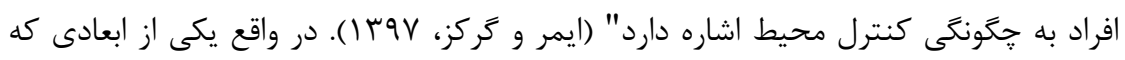

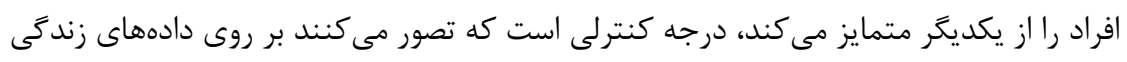

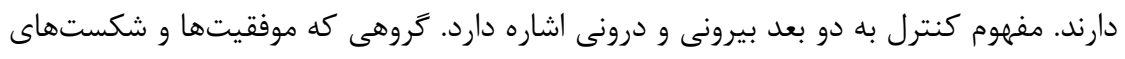

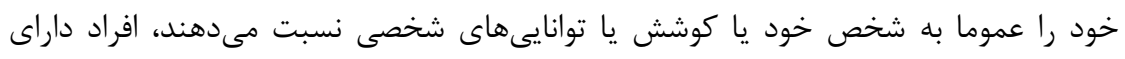

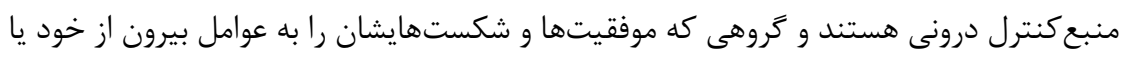

${ }^{1}$ Locus of control 
بخت و اقبال يا دشوارى موقعيتها نسبت مىدهند، افراد داراى منبع كنترل بيرونى هستند

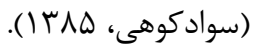

كسانى كه احساس كنترل بالا نسبت به رفتارشان دارند، احتمال كمترى دارد كه تصميمات غير اخلاقى بكيرند و احتمال بيشترى دارد كه براى تصميماتشان احساس مسئوليت كنند (نقل

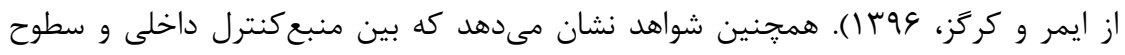

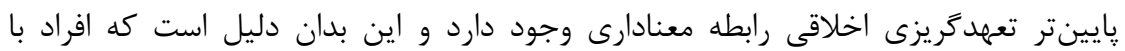
منبع كنترل داخلى كمتر احتمال دارد كه اقدام به رفتارهاى غيراخلاقى كنند (كورى و همكاران،

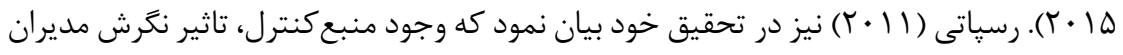

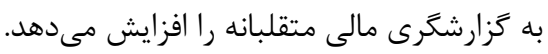

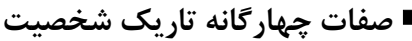

شخصيت، مفهومى است كه در روانشناسى بسيار مورد توجه بوده است. شخصيت مجموعهاى از ويزگ

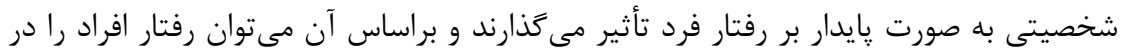

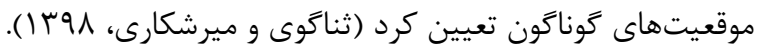

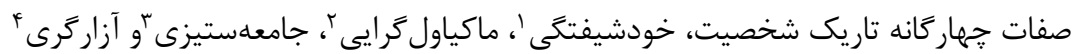
(ساديسم) را شامل مىشود. خودشيفتخى سبكى از شخصيت است كه با ويزگى هايى همجون خودبزرگبينى، تخيلات افراطى درباره قدرت، زيبايى و موفقيت، حساسيت زياد به انتقاد و

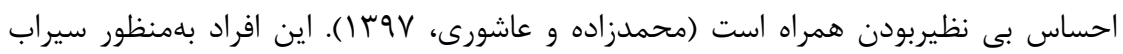
كردن وجودشان بيشازحد نياز به تاييد و تحسين ديكران دارند، اما در نهايت آسيبذِيرند و از

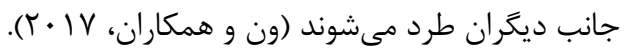
افراد ماكياول r. تمايل دارند از طريق رفتارهاى غير اخلاقى مانند دستكارى، بهره كشى و فريب به اهدافئ افشان

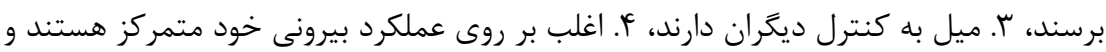
توجهى به عملكرد درونىشان ندارند (زيگلر و همكاران، 19 • ب). جامعهستيزى بهعنوان تكانشگرى بى يروا تعريف مىشود و افراد داراى جامعهستيزى قوى

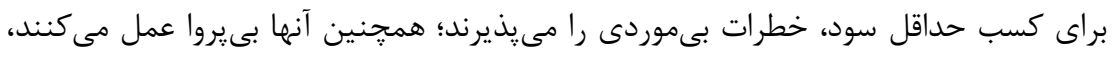

1 Narcissism

2 Machiavellianism

3 Psychopathy

${ }^{4}$ Sadism 
بع عاطفهاند، غير هيجانىاند، تكانش گرند، بهدنبال جلب احساسند و تمايلات ضد اجتماعى دارند

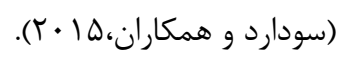

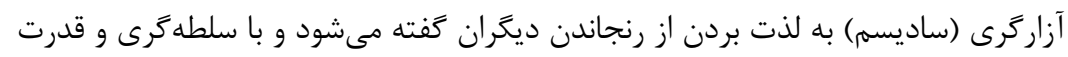

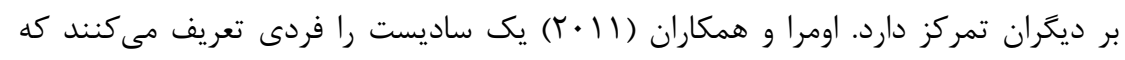

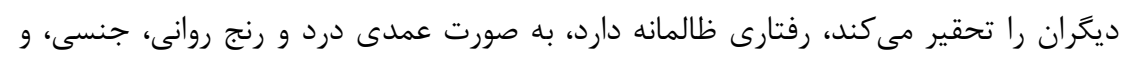

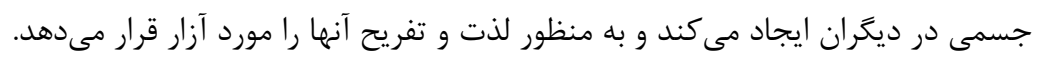

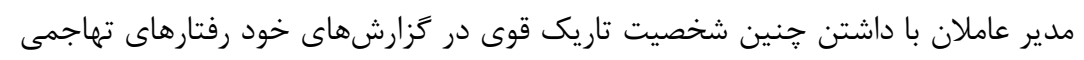

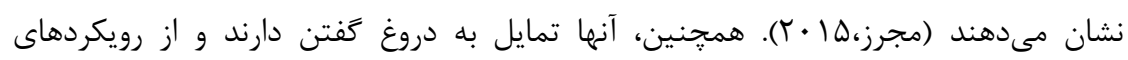

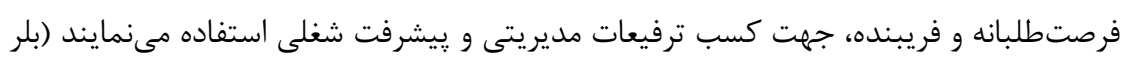

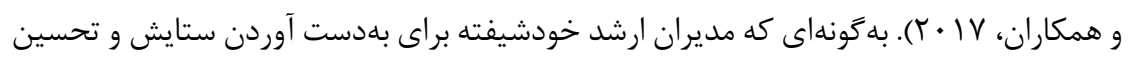

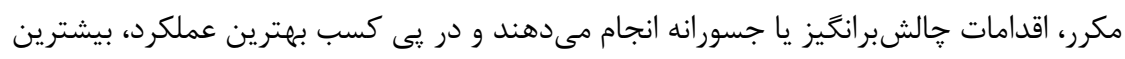

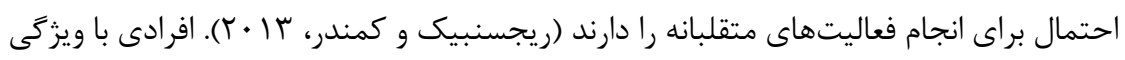

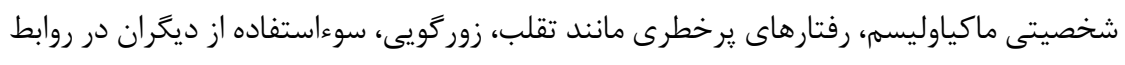

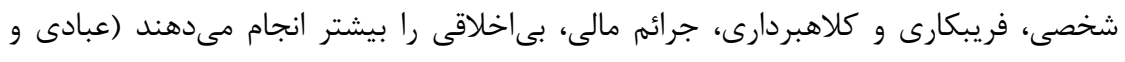

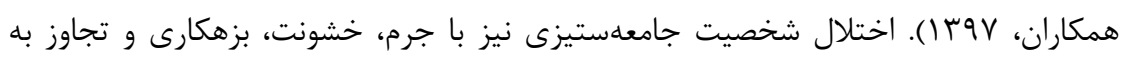

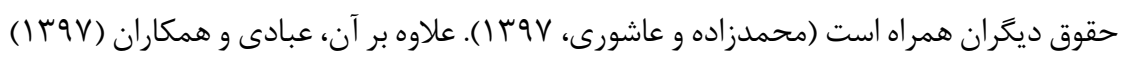

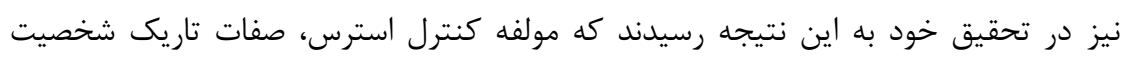

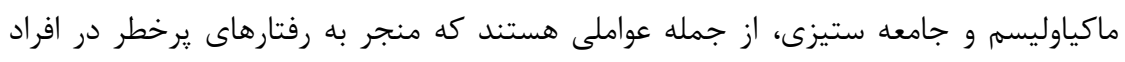

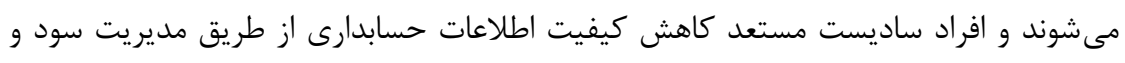

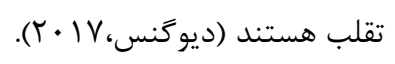

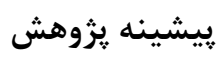

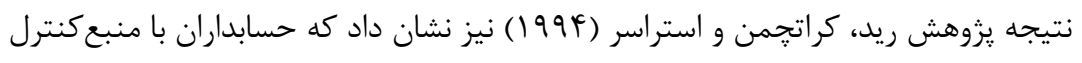

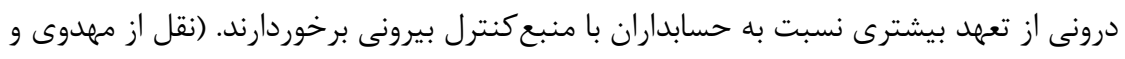

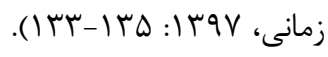

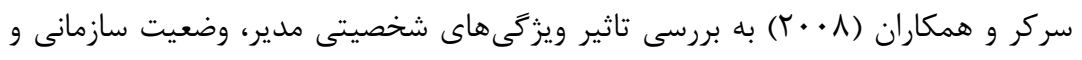

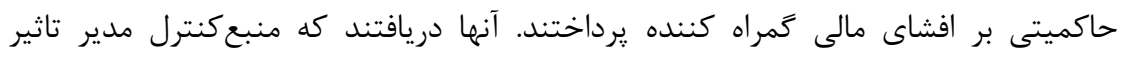

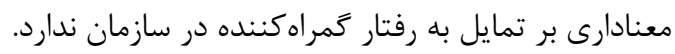

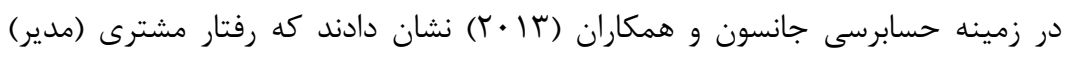
خودشيفته و انگَيزه تقلب با ارزيابى كلى خطر تقلب حسابرسان ارتباط مثبت و معنادارى دارد. 


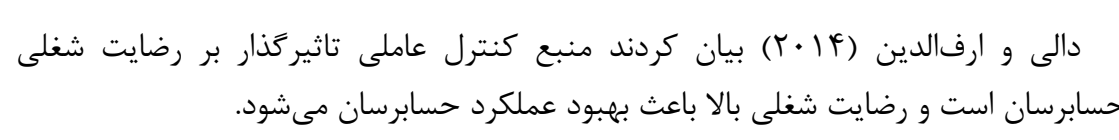

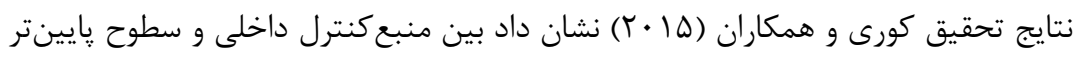

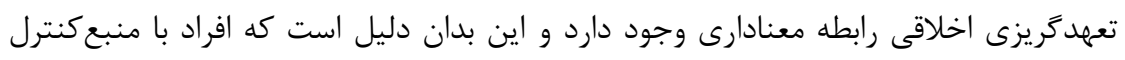

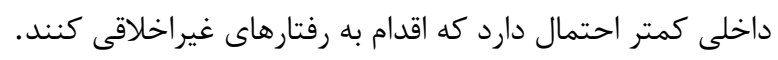

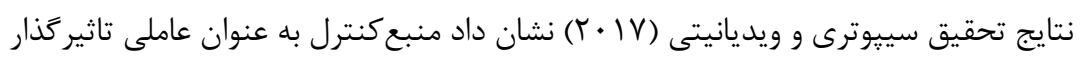
در عملكرد مديريت مىباشد.

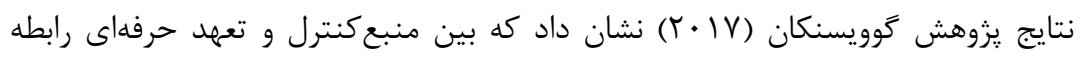
معنادارى وجود دارد.

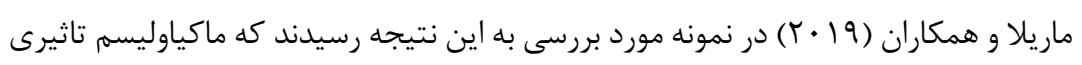
بر رفتار متقلبانه ندارد.

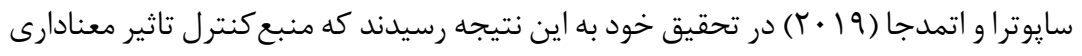
بر عملكرد حسابرسان داخلى دارد.

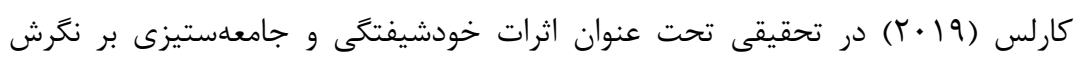

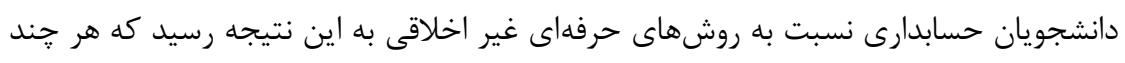

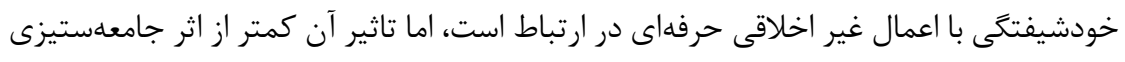

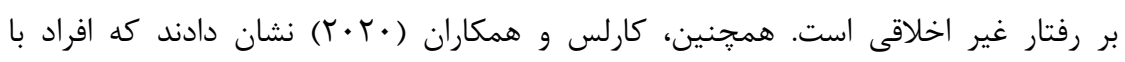

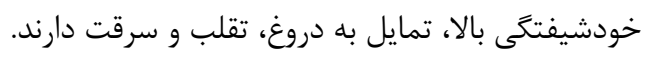

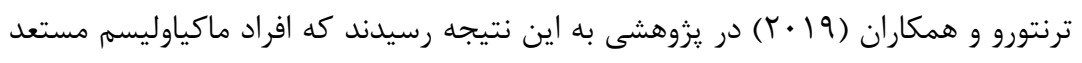

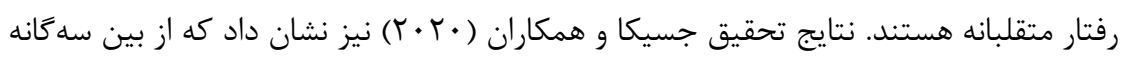

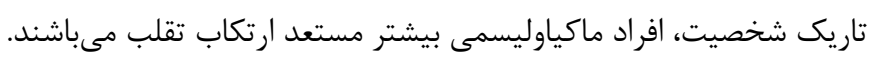

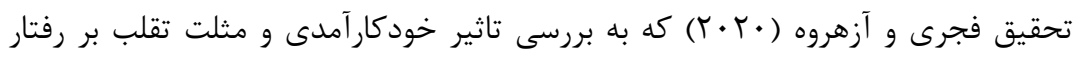

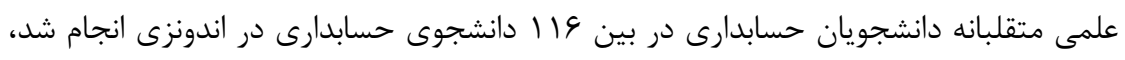

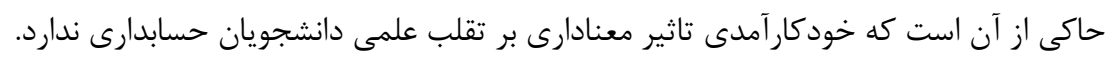

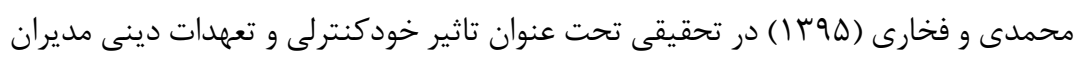

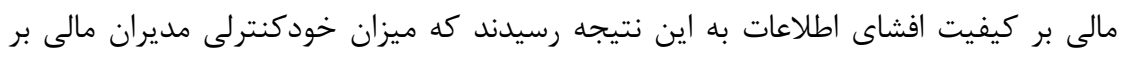
كيفيت افشاى اطلاعات تاثير مثبت دارد.

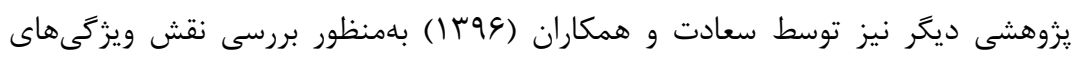

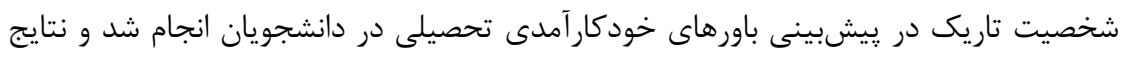


نشان داد كه صفات شخصيت جامعهستيزى و ماكياولى با خودكارآمدى تحصيلى در دانشجويان رابطه معنادار و منفى دارند.

نتايج تحقيق وكيلىفرد و همكاران (צوبا) نشاندهنده تاثير مستقيم و مثبت ميزان

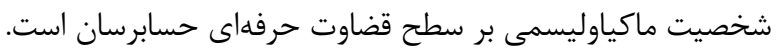

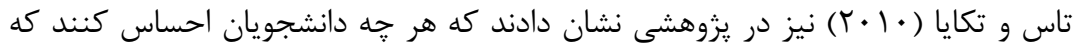

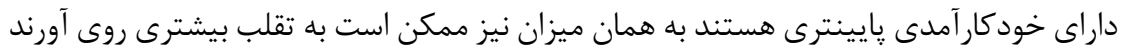

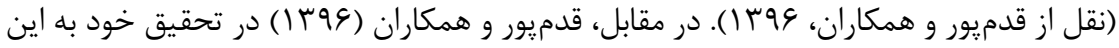

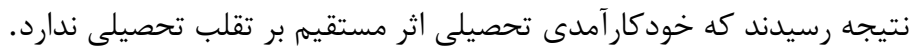

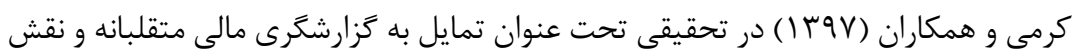

اخلاق يولى و تعهد اخلاقى، به اين نتيجه رسيد كه تعهد اخلاقى داراى رابطه منفى و معنى دارئ دارى

با تمايل به كَزارشكَرى مالى متقلبانه است.

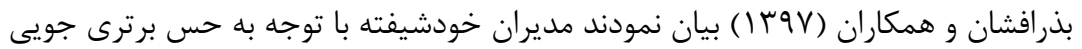

و خودبسندگى و اين احساس كه بالاتر از قانون هستند، يا را از حدود قدرتشان- كه نشات كرفته

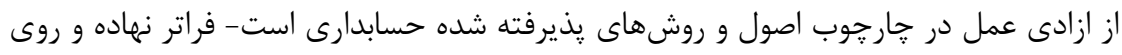

سود كزارش شده اثر مي كذارند.

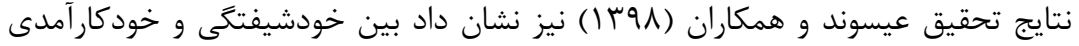

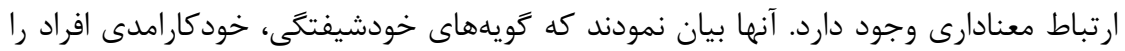

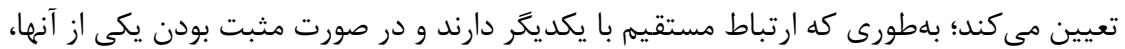

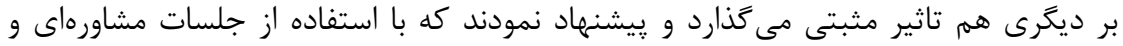

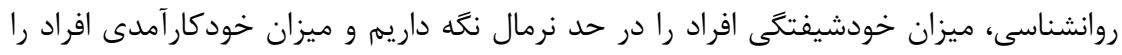

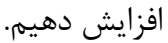

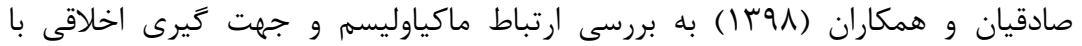

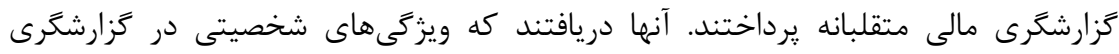

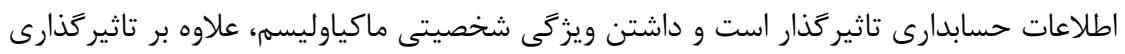

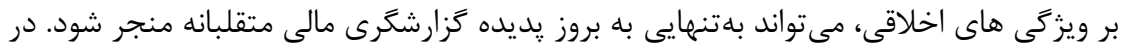

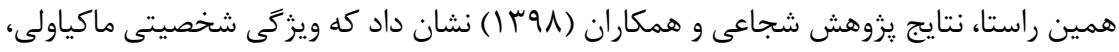

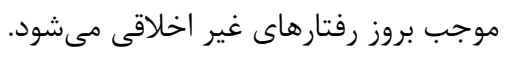

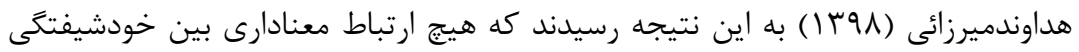

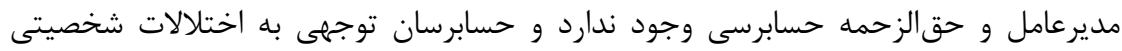
مديرعامل نداشته و آن را در برآورد حقى حقالزحمه حسابرسى مد نظر قرارد ورار نمى دهند. 


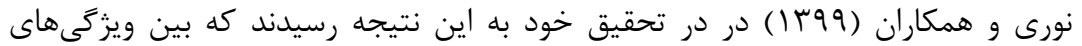

شخصيتى و خود كار آمدى رابطه معنادارى وجود دارد.

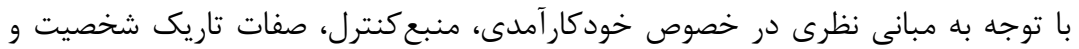

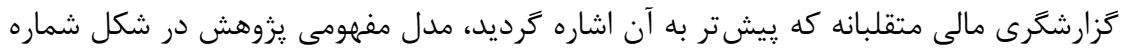

$$
\text { ا نشان داده شده است. }
$$

\section{شكل 1- مدل مفهومى يزوهش}

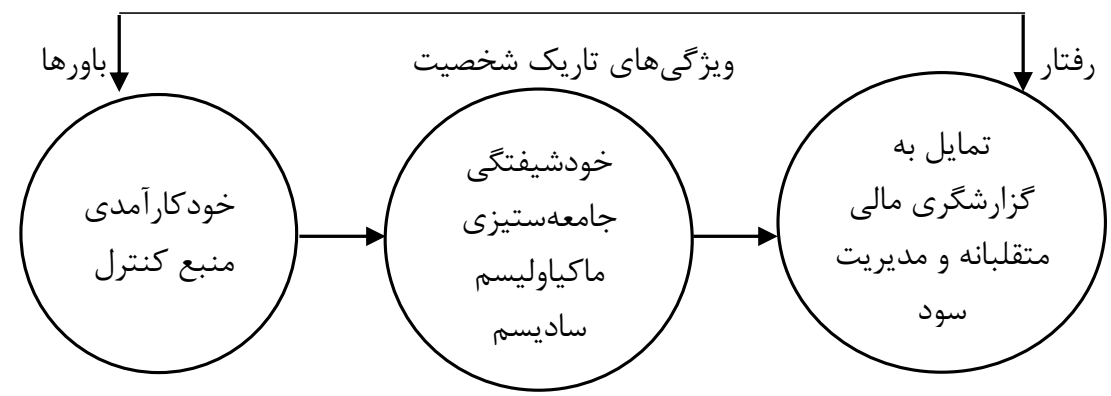

r-فرضيه هاى يزوهش

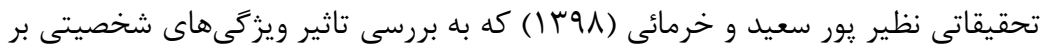

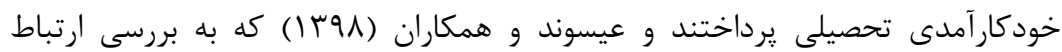
خودشيفتخى و خودكار آمدى يرداختند، ارتباط بين شخصيت و خودكارآمدى را رورد مود تاييد

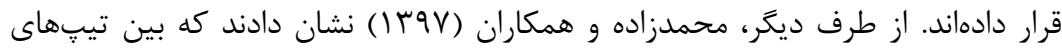

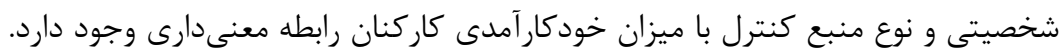
مطابق با مبانى نظرى و يیشينههاى تحقيق، خودكارآمدى و منبع كنترل بهعنوان عواملى

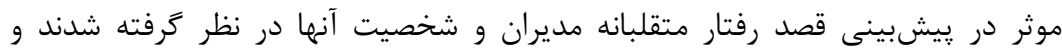
فرضيههاى زير تدوين خرديد:

فرضيه اول: خودكارآمدى بر خودشيفتگى مديران تاثير منفى و معنادارى دارد.

فرضيه دوم: خود كارآمدى بر جامعهستيزى مديران تاثير منفى و معنادارى دارد.

فرضيه سوم: خودكارآمدى بر ماكياوليستى مديران تاثير منفى و معنادارى دارد.

فرضيه جههارم: خودكارآمدى بر ساديسمى مديران تاثير منفى و معنادارى دارد.

فرضيه ينجم: منبع كنترل بر خودشيفتخى مديران تاثير منفى و معنادارى دارد.

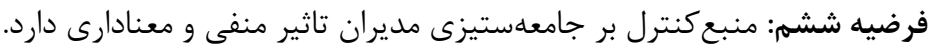

فرضيه هفتم: منبع كنترل بر ماكياوليستى مديران تاثير منفى و معنادارى دارد. فرضيه هشتهم: منبع كنترل بر ساديسمى مديران تاثير منفى و معنادارى دارد. 
باور خودكار آمدى بهعنوان يكى از مههمترين و اصلىترين عوامل در تبيين رفتارهاى انسانى

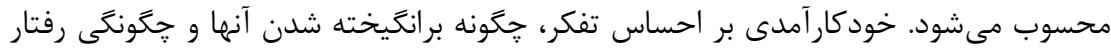

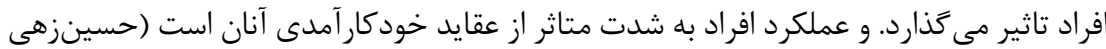

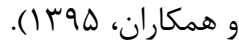

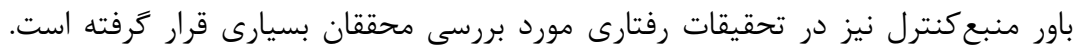

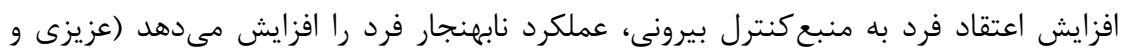

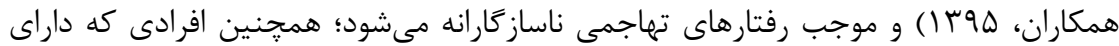

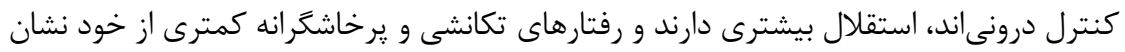

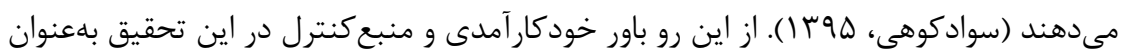

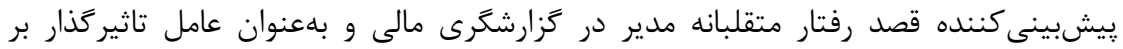

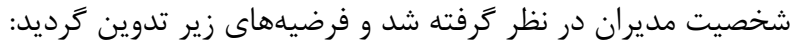

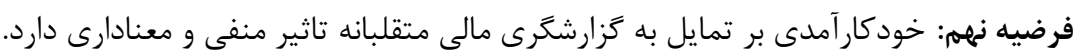

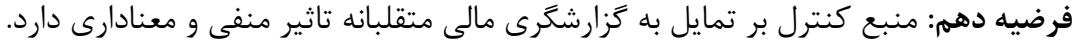

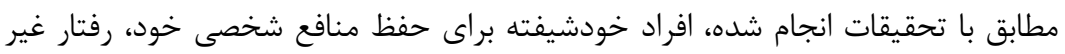

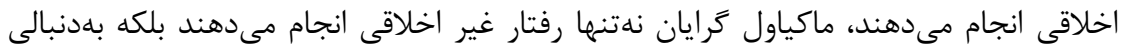

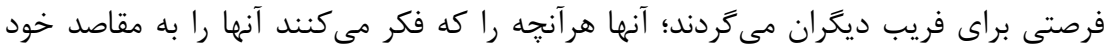

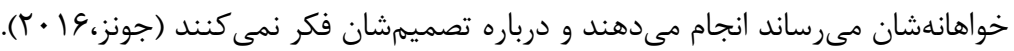

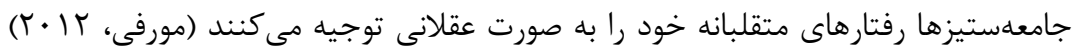

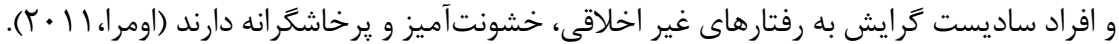

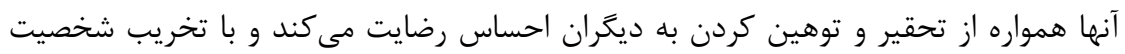

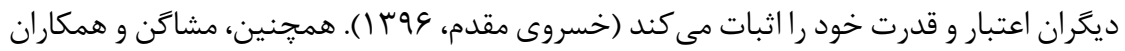

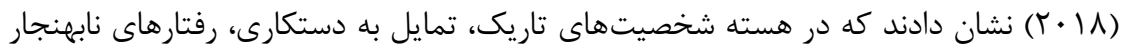
و خودمحورى ديده مىشود. بر طبق مبانى نظرى مطرح شده در اين زمينه، فرضيه هايى به شرح زير تدوين ترديد: فرضيه يازدهم: خودشيفتكى مديران بر تمايل به َزارشكرى مالى متقلبانه تاثير مثبت و معنادارى فرضيه دوازدهم: جامعهستيزى مديران بر تمايل به كزارشگرى مالى متقلبانه تاثير مثبت و

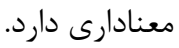
فرضيه سيزدهم: ماكياوليستى مديران بر تمايل به كزارشكرى مالى متقلبانه تاثير مثبت و

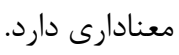


فرضيه جهاردهم: ساديسمى مدير ان بر تمايل به گزارشكَى مالى متقلبانه تاثير مثبت و معنادارى

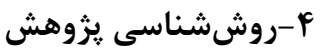

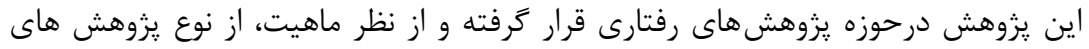

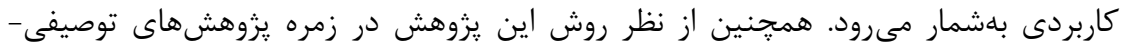

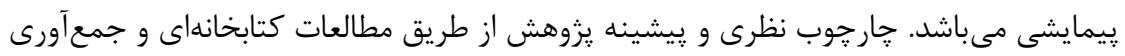

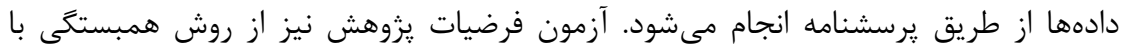
استفاده از مدلسازى معادلات' ساختارى انجام شده است.

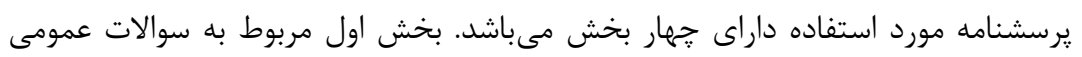

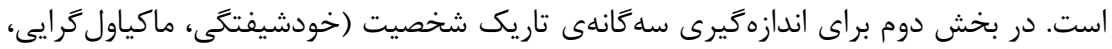

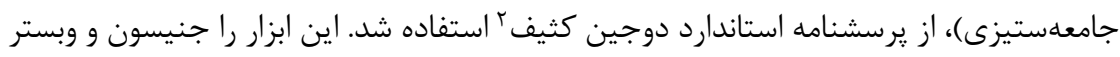

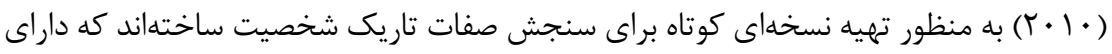

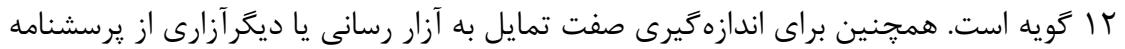

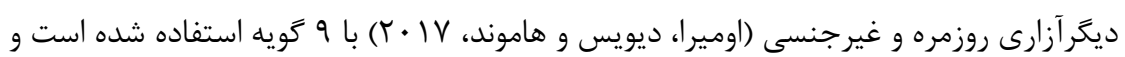

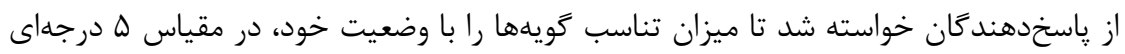

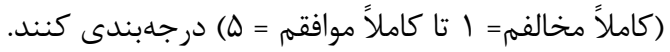

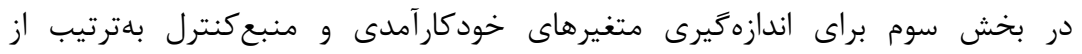

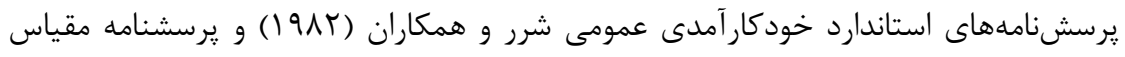

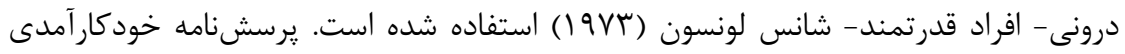

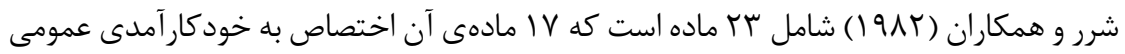

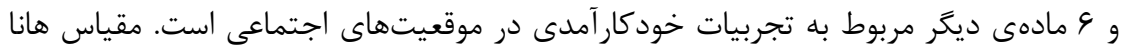

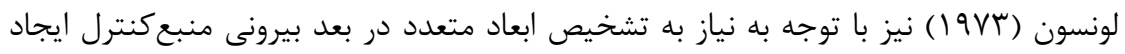

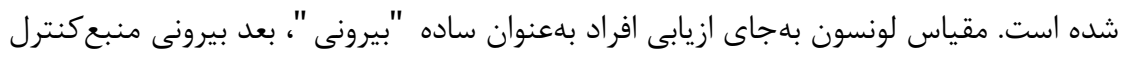

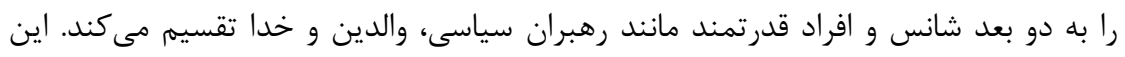

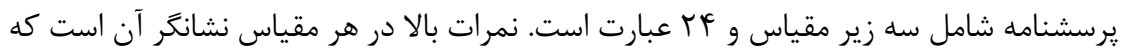

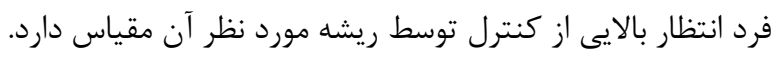

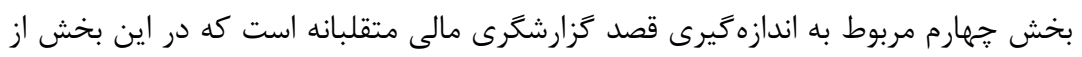

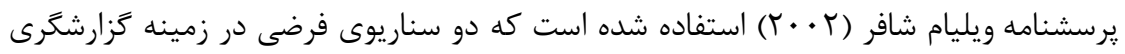

1 Structural Equation Model 2 Dirty dozen 
مالى متقلبانه- با فرض دستكارى بالهميت و كماهميت را به تصوير مى كشد و در هر سناريو

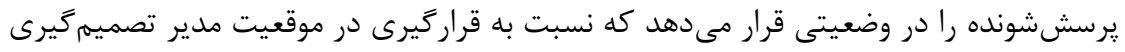
نمايد.

به منظور حصول اطمينان از روايى يرسشنامه، از روش روايى صورى استفاده شد و سوالات

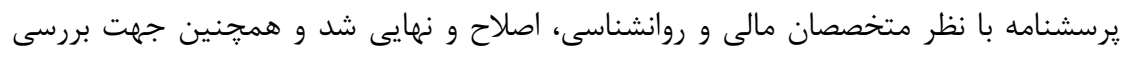

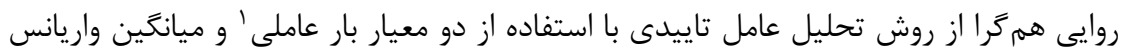

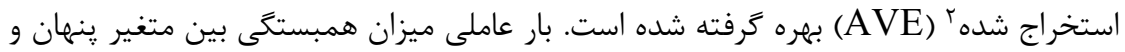

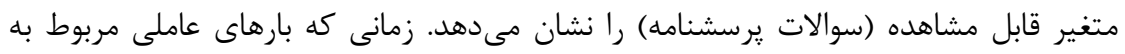

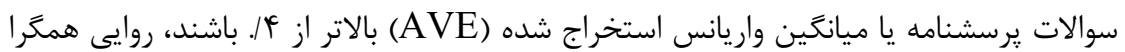

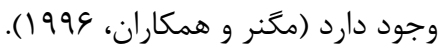

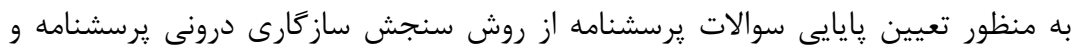

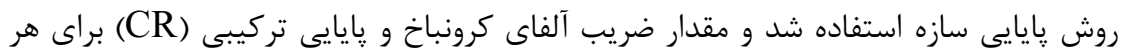

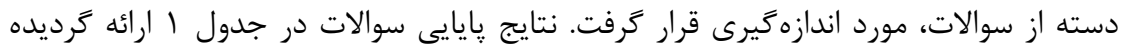

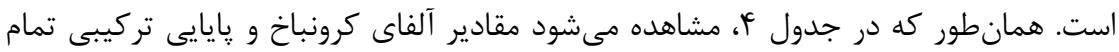

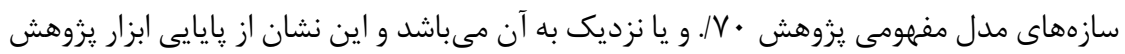

جدول شمارها. نتايج مربوط به پايايى سازههاى مدل مفهومى يزوهش

\begin{tabular}{|c|c|c|}
\hline آلفاى كرونباخ & يايايى تركيبى & سازه \\
\hline$\cdot|\Lambda| \Delta$ & $\cdot \mid 1199$ & خود كار آمدى \\
\hline$\cdot 19 \cdot 1$ & $\cdot|V \Delta|$ & 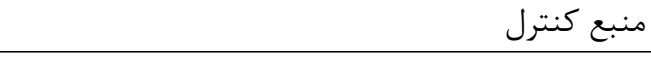 \\
\hline 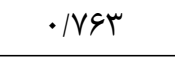 & $\cdot$. MAT & خودشيفتخى \\
\hline$\cdot 19 \Delta 1$ & $\cdot|\Lambda| 1$ & جامعهستيزى \\
\hline$\cdot|\Lambda| F$ & $\cdot \mid \wedge \vee V$ & 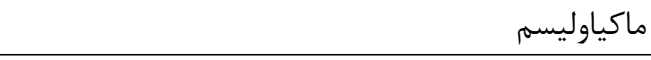 \\
\hline 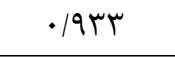 & .19 fr & 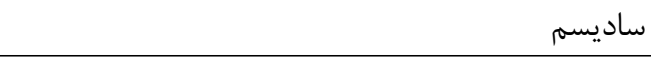 \\
\hline$\cdot 19 \cdot 1$ & $\cdot 1994$ & ززرشخرى مالى متقلبانه- دستكارى با الهميت در سود \\
\hline$\cdot 19 \cdot 4$ & $\cdot / \mathrm{V} \mid 1$ & گزرشگَرى مالى متقلبانه- دستكارى كم|هميت در سود \\
\hline
\end{tabular}

1 Factor Loading

2 Average Variance Extracted 
جامعه آمارى يروهش حاضر حسابداران و مديران مالى شركتهاى يذيرفته شده در بورس

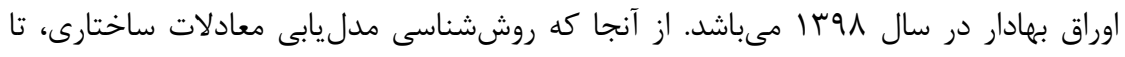

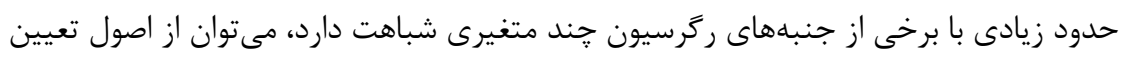

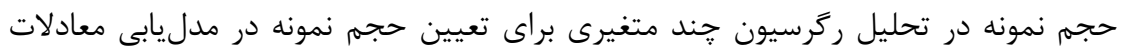

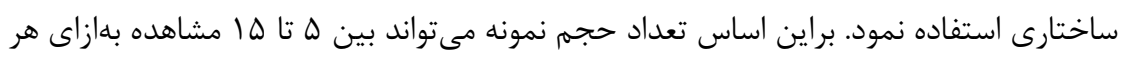

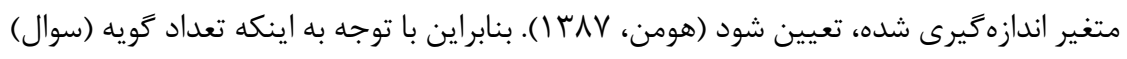

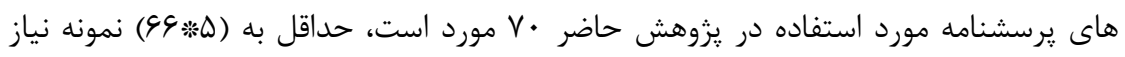

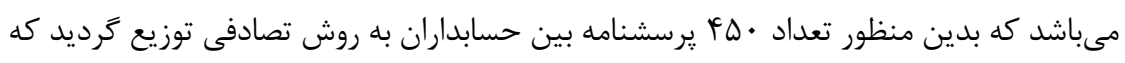

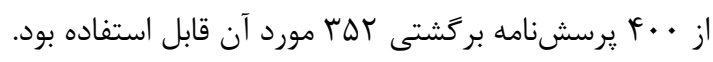
جهت تجزيه و تحليل دادهاى يثزوهش و بر اساس مدل مفهومى مطرح شده ، نمودارها و و

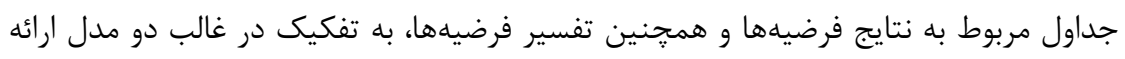

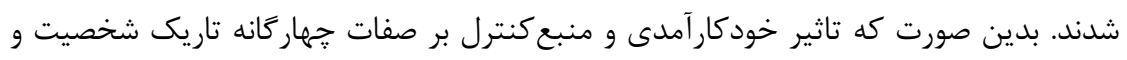
كزارشخرى مالى متقلبانه در مدل اول با فرض دستكارى بااهميت در سود و در در مدل دود دوم با فرض

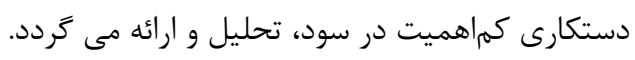
ه-يافته هاى يثروهش دين در اين بخش ابتدا به آمار توصيفى و سيس به بررسى فرضيات يزوهش يرداخته شده است.

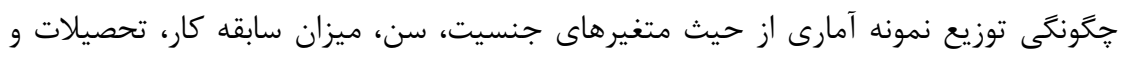

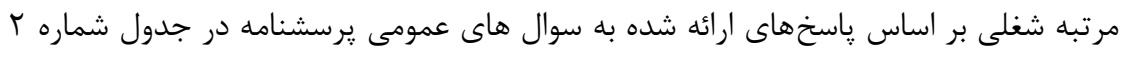
به صورت خلاصه ارائه شده است. جدول شماره ז. آمار توصيفى ياسخدهندًان

\begin{tabular}{|c|c|c|c|}
\hline درصد & تعداد & عنوان & \\
\hline זr & $11 \mathrm{~V}$ & مرد & \multirow[t]{2}{*}{ جنسيت } \\
\hline $9 V$ & rma & زن & \\
\hline ir & FF & كمتر از • r & \multirow{4}{*}{ سن } \\
\hline$\Delta T$ & 111 & بين •r-r & \\
\hline re & 91 & بين •f- & \\
\hline 9 & س & بالاتر از • ه & \\
\hline f & iv & كاردانى & \multirow{3}{*}{ تحصيلات } \\
\hline 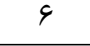 & $r \cdot$ & دانشجوى كارشناسى & \\
\hline +1 & 148 & كارشناسى & \\
\hline
\end{tabular}




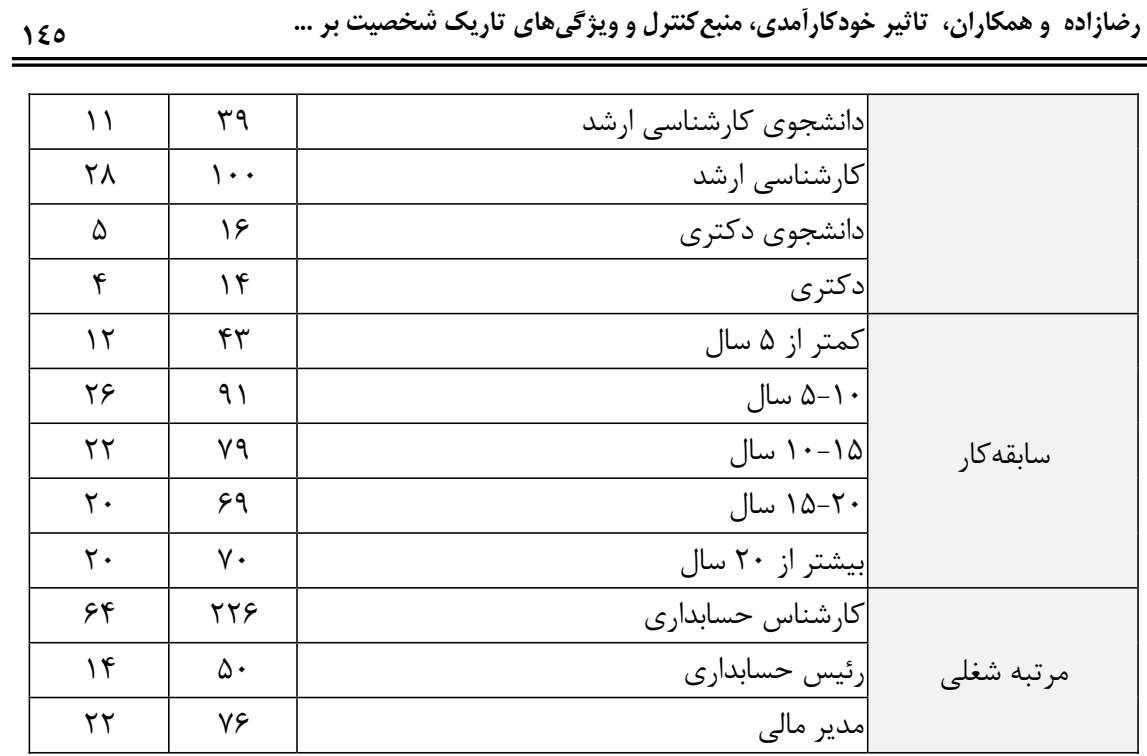

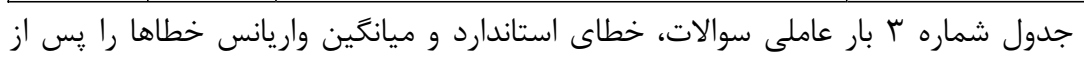

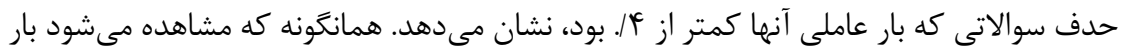

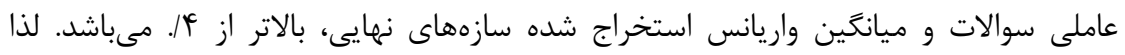

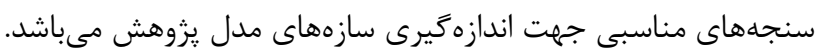

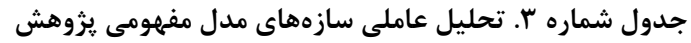

\begin{tabular}{|c|c|c|c|c|}
\hline AVE & خطانداى & عاملى & كويه & سازه \\
\hline \multirow{6}{*}{.$/ 011$} & - IFAT & . MT. & $\mathrm{Q}_{7}$ & \multirow{6}{*}{ خود كارآمدى } \\
\hline & $\cdot 10 \cdot r$ & $\cdot / V \cdot \Delta$ & $\mathrm{Q}_{12}$ & \\
\hline & - $/ D F F$ & $.19 \vee \Delta$ & $\mathrm{Q}_{13}$ & \\
\hline &.$/ 4 I V$ & - IVAY & $\mathrm{Q}_{14}$ & \\
\hline & $\cdot / 4 \wedge \Delta$ & $\cdot / \mathrm{V} / \mathrm{A}$ & $\mathrm{Q}_{16}$ & \\
\hline &.$/ 4 \Delta 9$ & ./VYG & $\mathrm{Q}_{17}$ & \\
\hline \multirow{3}{*}{.1019} & $\cdot / T I V$ & $\cdot / \wedge \wedge \Delta$ & $\mathrm{Q}_{14}$ & \multirow{3}{*}{ منبع كنترل } \\
\hline & $\cdot 11 \cdots$ & . IFFV & $\mathrm{Q}_{15}$ & \\
\hline & . IFTV & $\cdot / V \Delta V$ & $\mathrm{Q}_{21}$ & \\
\hline \multirow[b]{3}{*}{$\cdot \mid \Delta V V$} &.$/ \mu F$. & $\cdot / \mathrm{N} \mid \mathrm{T}$ & $\mathrm{Q}_{1}$ & \multirow{3}{*}{ خودشيفتگى } \\
\hline & $\cdot / 419$ & - /ATV & $\mathrm{Q}_{2}$ & \\
\hline & $\cdot / v \cdot 1$ & $\cdot / \Delta F$. & $\mathrm{Q}_{3}$ & \\
\hline
\end{tabular}


دو فصلنامه حسابدارى ارزشى و رفتارى، سال ينجم، شماره دهم، پِاييز و زمستان وجسا

\begin{tabular}{|c|c|c|c|c|}
\hline & . MTG & . $|A T|$ & $\mathrm{Q}_{4}$ & \\
\hline \multirow{3}{*}{$\cdot 10 \wedge 9$} &.$/ \mathrm{kF}$ & $\cdot \mid V F \Lambda$ & $\mathrm{Q}_{2}$ & \multirow{3}{*}{ جامعهستيزى } \\
\hline & $\cdot / r \wedge F$ & $\cdot / V \wedge \Delta$ & $\mathrm{Q}_{3}$ & \\
\hline & $\cdot|f|$ & - IVGA & Q4 & \\
\hline \multirow{4}{*}{. $\mid 94}$. & $\cdot / 4 \cdot 1$ & - IVVF & $\mathrm{Q}_{1}$ & \multirow{4}{*}{ ماكياوليسم } \\
\hline & $\cdot / 419$ & . IATV & $\mathrm{Q}_{2}$ & \\
\hline & $\cdot / 4 \cdot r$ & $\cdot / V V T$ & $\mathrm{Q}_{3}$ & \\
\hline &.$/ 119$ & - IATD & $\mathrm{Q}_{4}$ & \\
\hline \multirow{9}{*}{ - 19DT } & . MTY & ./VG. & $\mathrm{Q}_{1}$ & \multirow{9}{*}{ ساديسم } \\
\hline &.$/ T r \Delta$ & . IATK & $\mathrm{Q}_{2}$ & \\
\hline &.$/ T M \Lambda$ & - MAFF & $\mathrm{Q}_{3}$ & \\
\hline & • & .1119 & $\mathrm{Q}_{4}$ & \\
\hline &.$/ 4 \wedge 9$ & . IAFT & $\mathrm{Q}_{5}$ & \\
\hline &.$/ T V V$ & $\cdot / \wedge \Delta \cdot$ & $\mathrm{Q}_{6}$ & \\
\hline & . & . /VqV & $\mathrm{Q}_{7}$ & \\
\hline & $.|F| \mid$ & $\cdot / V F \Lambda$ & $\mathrm{Q}_{8}$ & \\
\hline & . /rqq & $\cdot / V \vee q$ & $\mathrm{Q}_{9}$ & \\
\hline \multirow[b]{2}{*}{$\cdot 10 \cdot$} & $\cdot / 4 \Delta V$ & . IVTV & $\mathrm{Q}_{1}$ & \multirow{2}{*}{ گززرشخَى مالى متقلبانه- دستكارى با اهميت در سود } \\
\hline & $\cdot 100$ & $\cdot|9 V|$ & $\mathrm{Q}_{2}$ & \\
\hline \multirow[b]{2}{*}{ - $/ \Delta \Delta r$} & $\cdot / \mu c$ & $\cdot 1 \wedge \cdots$ & $\mathrm{Q}_{1}$ & \multirow{2}{*}{ حَزرشَّىى مالى متقلبانه- دستكارى كماهميت در سود } \\
\hline & $\cdot / \Delta r \Delta$ &.$/ 91 \mathrm{t}$ & $\mathrm{Q}_{2}$ & \\
\hline
\end{tabular}

براى تاييد يا رد فرضيههاى يزوهش در مدل ساختارى، مقادير آماره آزمون تى يا سطح

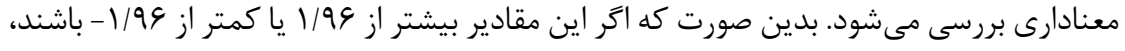

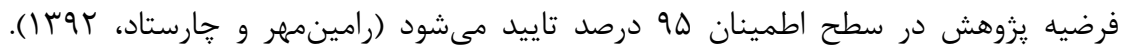

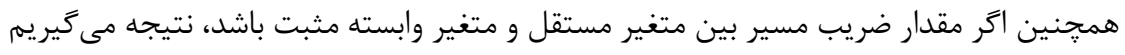

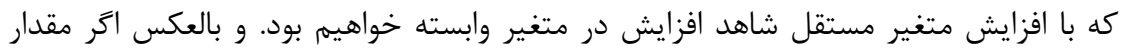

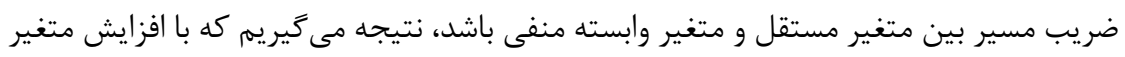
مستقل شاهد كاهش در متغير وابسته خواهيم بود.

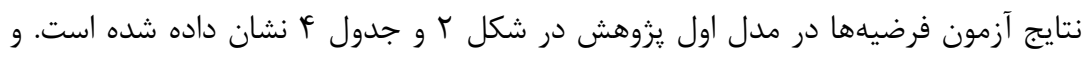

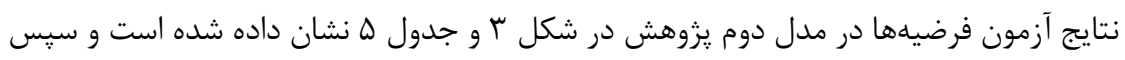




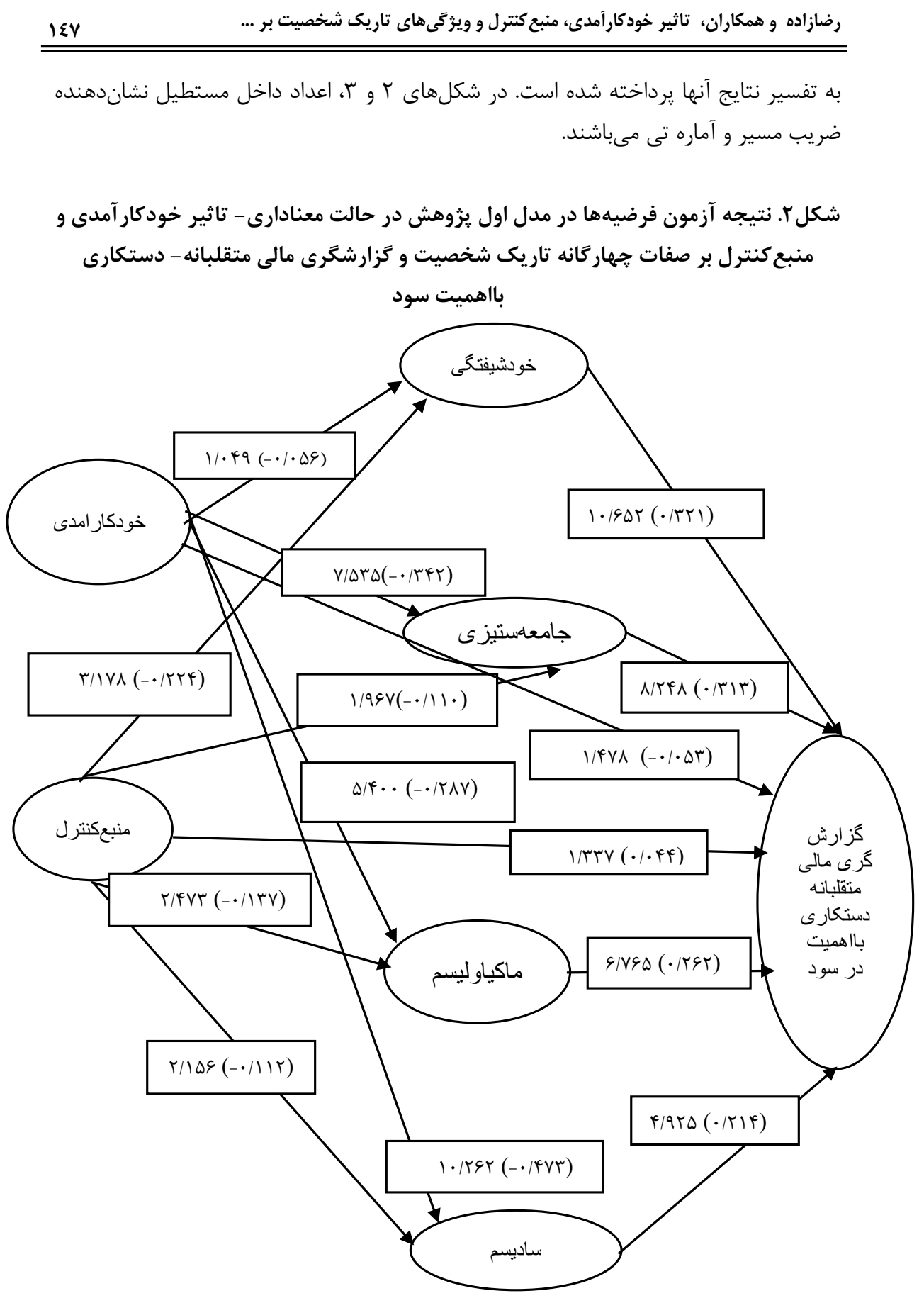


دو فصلنامه حسابدارى ارزشى و رفتارى، سال ينجم، شماره دهم، پِاييز و زمستان وجسا

جدول شماره F. نتايج آزمون فرضيههاى يزوهش در مدل اول با فرض دستكارى باهميت

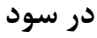

\begin{tabular}{|c|c|c|c|c|}
\hline 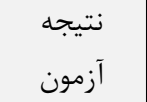 & آماره تى & 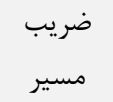 & |فرضيهها & شماره فرضيه \\
\hline رد فرضيه & $1 / .49$ & $-\cdot / \cdot \Delta \varphi$ & |تأثير خودكارآمدى بر خودشيفتكى & فرضيه اول \\
\hline تاييد فرضيه & V/ara & - - MTt & |تأثير خودكارآمدى بر جامعهستيزى & فرضيه دوم \\
\hline تاييد فرضيه & $\Delta / \uparrow \cdots$ & $-\cdot / r \wedge \vee$ & |تأثير خودكار آمدى بر ماكياوليسم & فرضيه سوم \\
\hline تاييد فرضيه & $1 \cdot / r 94$ & $-\cdot /$ FVM & |تأثير خودكار آمدى بر ساديسم & فرضيه جهارم \\
\hline تاييد فرضيه & $r / l \vee \wedge$ & $-\cdot /$ TYF & |تأثير منبع كنترل بر خودشيفتكى & فرضيه ينجم \\
\hline تاييد فرضيه & $1 / 99 V$ & $-\cdot / 11$ & تأثير منبع كنترل بر جامعه ستيزى & فرضيه ششم \\
\hline تاييد فرضيه & r/FVr & $-\cdot / 1 T \mathrm{~V}$ & |تأثير منبع كنترل بر ماكياوليسم & فرضيه هفتم \\
\hline تاييد فرضيه & $r / \backslash \Delta S$ & $-\cdot 111 r$ & تأثير منبع كنترل بر ساديسم & فرضيه هشتم \\
\hline رد فرضيه & $1 / 4 \vee \wedge$ & $-\cdot \cdot \cdot \Delta r$ & تأثير خود كار آمدى بر گزارشگَرى مالى متقلبانه & فرضيه نهم \\
\hline رد فرضيه & $1 / r r v$ & $\cdot 1 \cdot$ tf & تأثير منبع كنترل بر گزارشگرى مالى متقلبانه & فرضيه دهم \\
\hline تاييد فرضيه & $1 \cdot 19 \Delta T$ & . ITt & تأثير خودشيفتخى بر گزارشگرى مالى متقلبانه & فرضيه يازدهم \\
\hline تاييد فرضيه & $\Lambda / T F \Lambda$ & 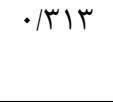 & متقلبانه & فرضيه دوازدهم \\
\hline تاييد فرضيه & G/VGD & $\cdot$ / TAT & تأثير ماكياوليسم بر گزارشگَىى مالى متقلبانه & فرضيه سيزدهم \\
\hline تاييد فرضيه & $r / 9 r \Delta$ & $\cdot / T \mid f$ & |تأثير ساديسم بر گزارشخَرى مالى متقلبانه & جرضيه \\
\hline
\end{tabular}

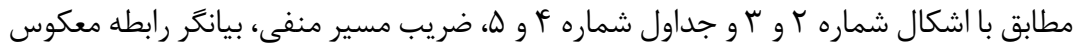

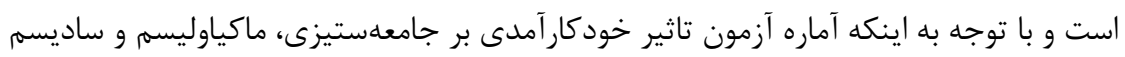

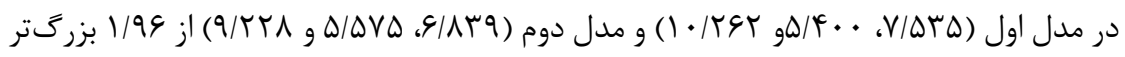

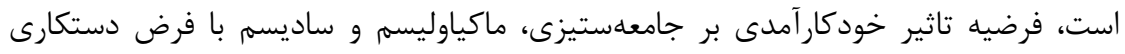
باهميت و كم/هميت در سطح اطمينان له درصد (فرضيه دوم، سوم و جهارم) تاييد مى مشود.

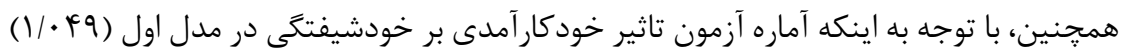

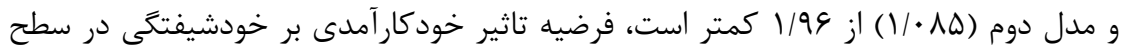

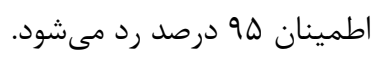




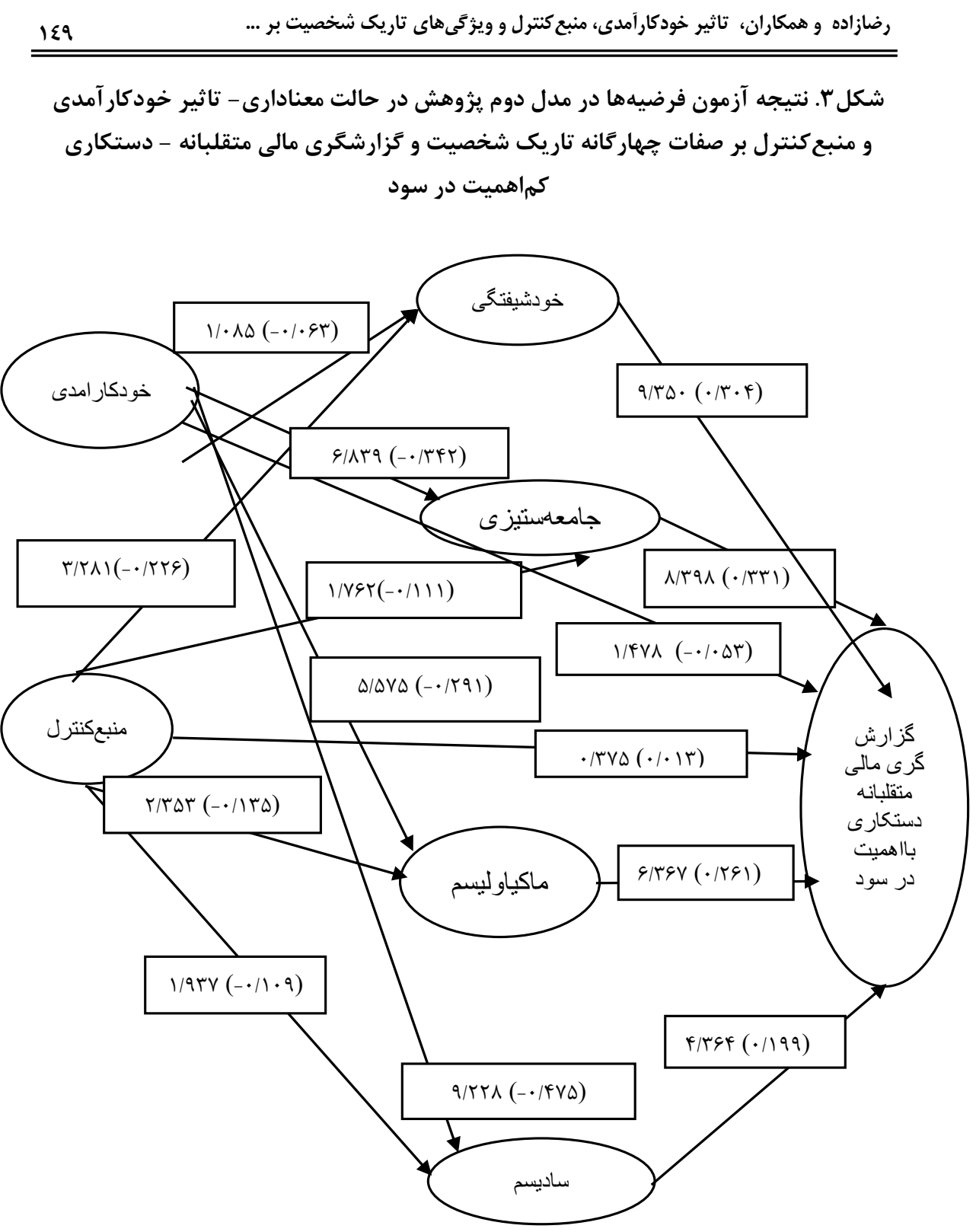


دو فصلنامه حسابدارى ارزشى و رفتارى، سال ينجم، شماره دهم، پِاييز و زمستان وجسا

\begin{tabular}{|c|c|c|c|c|}
\hline \multicolumn{5}{|c|}{ جدول شماره ه. نتايج آزمون فرضيههاى ثزوهش در مدل دوم دستكارى كم/اهميت در سود } \\
\hline آزتيجه & تى & ضريب & فرضيهها & شماره فرضيه \\
\hline رد فرضيه & $1 / \cdot \wedge \Delta$ & $-.1 \cdot 94$ & |تأثير خود كار آمدى بر خودشيفتكى & |فرضيه اول \\
\hline ت تاييد فرضيه & $9 / 1 \mu q$ & $-\cdot /$ HTt & |تأثير خود كارآمدى بر جامعهستيزى & 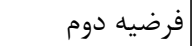 \\
\hline تاييد فرضيه & $\Delta / \Delta \vee \Delta$ & $-\cdot / 491$ & تأثير خودكارآمدى بر ماكياوليسم & فرضيه سوم \\
\hline تاييد فرضيه & 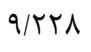 & $-\cdot / \& V \Delta$ & تأثير خود كارآمدى بر ساديسم & |فرضيه جهارم \\
\hline تاييد فرضيه & $r / r \wedge l$ &.$- / T T S$ & تأثير منبع كنترل بر خودشيفتكى & فرضيه ينجم \\
\hline رد فرضيه & IVAT & $-\cdot 1111$ & |تأثير منبع كنترل بر جامعه ستيزى & |فرضيه ششم \\
\hline تاييد فرضيد & r/Tur &.$- / 1 r \Delta$ & تأثير منبع كنترل بر ماكياوليسم & فرضيه هفتم \\
\hline تاييد فرضيه & 1/9rV & $-\cdot 11 \cdot 9$ & |تأثير منبع كنترل بر ساديسم & 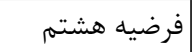 \\
\hline رد فرضيه & I/IFV & $-\cdot / \cdot r \cdot$ & تأثير خود كار آمدى بر كَزارشَرى مالى متقلبانه & |فرضيه نهمم \\
\hline رد فرضيه & $\cdot / \pi V \Delta$ &.$/ \cdot 14$ & |تأثير منبع كنترل بر گزارشكَى مالى متقلبانه & فرضيه دهم \\
\hline تاييد فرضيه & $q / \Gamma \Delta \cdot$ & $\cdot / \mu \cdot \hat{q}$ & تأثير خودشيفتگى بر ززارشخرى مالى متقلبانه & فرضيه يازدهم \\
\hline تاييد فرضيه & $\Lambda / \mu q \Lambda$ & 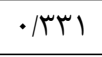 & تأثير جامعلستيزى بر گزارشگرى مالى متقلبانه & فرضيه دوازدهم \\
\hline تاييد فرضيه & G/MGV & $\cdot \mid r 91$ & تأثير ماكياوليسم بر گززارشخَى مالى متقلبانه & فرضيه سيزدهم \\
\hline ت تاييد فرضيه & F/rGY & .1199 & |تأثير ساديسم بر گزارشگرى مالى متقلبانه & فرضيه جهاردهم \\
\hline
\end{tabular}

همجنين با توجه به منفى بودن ضريب مسير كه بيانگر رابطه معكوس است و اينكه آماره

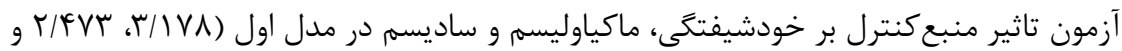
צه/ بر خودشيفتكى، ماكياوليسم و ساديسم با فرض دستكارى بالهميت و كماهميت در سطح اطمينان هو درصد (فرضيه ينجم، هفتم و هشتم) تاييد مى شود. همجنين، با توجه به اينكه آماره آزمون

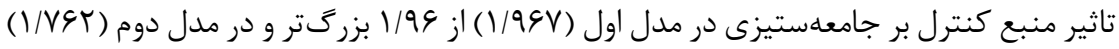

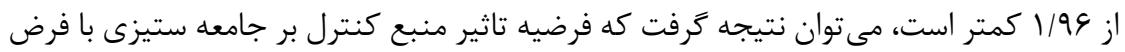

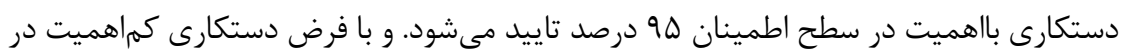

$$
\text { سطح اطمينان فه درصد رد مىشود. }
$$

با توجه به اينكه آماره آزمون تاثير خودكارآمدى و منبع كنترل بر زَارشكَرى مالى متقلبانه

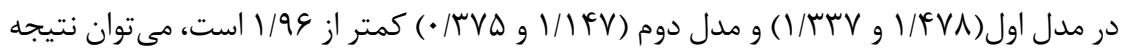
گرفت كه خودكارآمدى و منبع كنترل تاثير معنادارى بر زَزارشگرى مالى متقلبانه ندارد و فرضيه

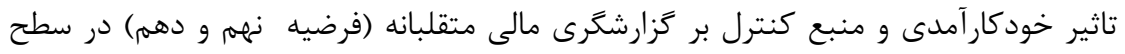


اطمينان ه9 درصد رد مى خردد. به بيان ديگر، باور خودكارآمدى و منبع كنترل مديران تاثيرى بر قصد رفتارى متقلبانه مديران ندارد.

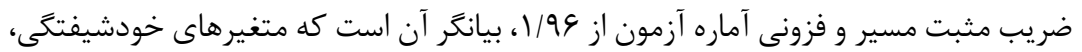

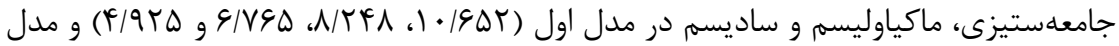

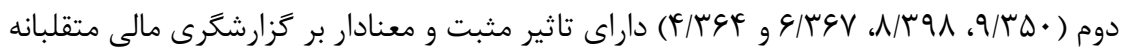

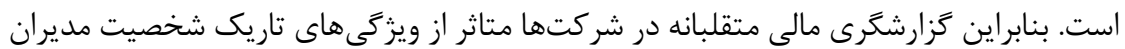
است. و فرضيه تاثير متغيرهاى خودشيفتتى، جامعهستيزى، ماكياوليسم و ساديسم بر تزارشكرى مالى متقلبانه در سطح اطمينان هو درصد تاييد مىشود.

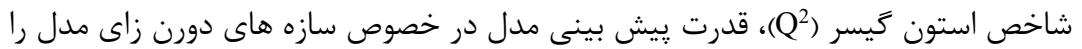

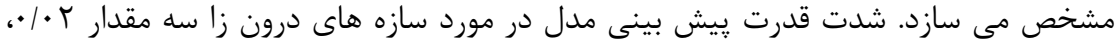

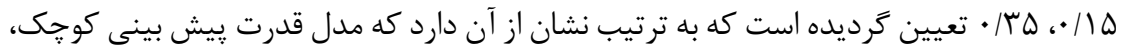
متوسط و بزرى در قبال شاخص هاى آن سازه دارد .

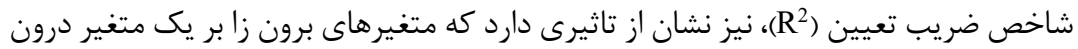

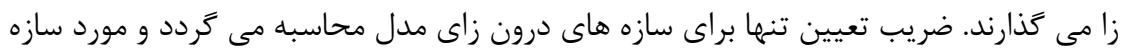

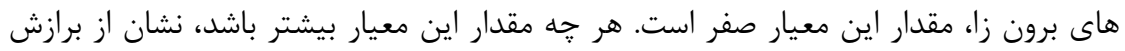

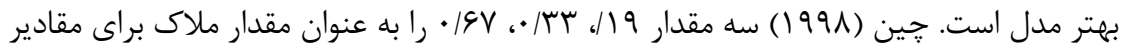
ضعيف، متوسط و قوى ضريب تعيين معرفى مى كند.

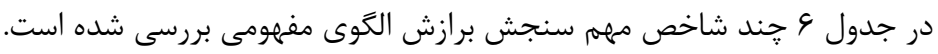

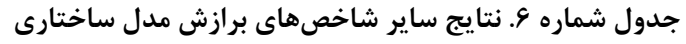

\begin{tabular}{|c|c|c|c|c|c|c|}
\hline \multicolumn{2}{|c|}{ ضريب تعيين } & \multicolumn{2}{|c|}{ مقادير اشتراكى } & \multicolumn{2}{|c|}{ استون تيسر } & \multirow[t]{2}{*}{ متغير } \\
\hline مدل دوم & مدل اول & مدل دوم & مدل اول & مدل دوم & مدل اول & \\
\hline - & - &.$/ 011$ &.$/ 011$ & - & - & خود كارآمدى \\
\hline - & 一 & .1019 & $\cdot / 019$ & - & 一 & منبع كنترل \\
\hline.$/ \cdot 71$ &.$/ .01$ & $.10 \mathrm{VV}$ & $\cdot / 0 \mathrm{VV}$ & $\cdot / \cdot Y \Lambda$ & $\cdot / \cdot Y V$ & خودشيفتكى \\
\hline$\cdot / \backslash \varepsilon r$ & $\cdot / / \varepsilon \varepsilon$ & $\cdot / 019$ & $\cdot / 019$ & $\cdot / \cdot v q$ & $\cdot / \cdot v q$ & جامعه ستيزى \\
\hline$\cdot / 1 \mathrm{~V}$ & $\cdot / 117$ & $\cdot / \neg \varepsilon$. & $\cdot / 7 \varepsilon$ & $\cdot / \cdot u$ & $\cdot / \cdot \eta$ & ماكياوليسم \\
\hline.$/$ ror & $\cdot /$ ror & . /70r & ./70r & $\cdot / 17 \varepsilon$ & $\cdot / 17 \varepsilon$ & ساديسم \\
\hline$\cdot / 7 V r$ & •/UNr & $\cdot 1090$ &.$/ 090$ & • & • & كزارشكرى مالى متقلبانه \\
\hline
\end{tabular}


همانطور كه در جدول شماره 9 نشان داده شده است، در مدل اول و دوم يزوهش، قدرت

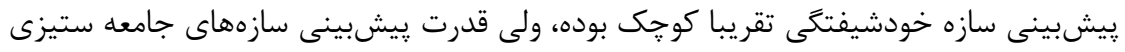

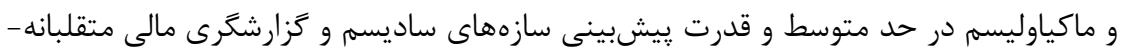

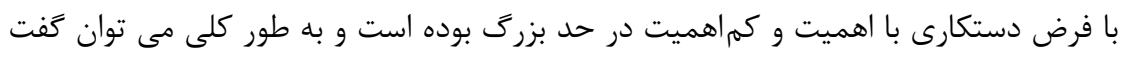

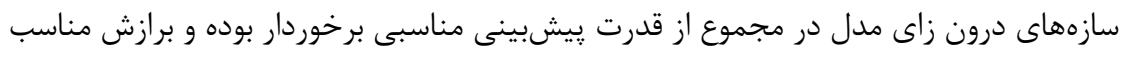
مدل ساختارى را تأئيد مى كند.

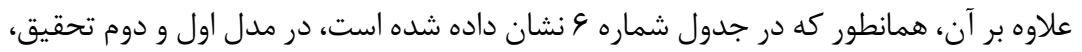

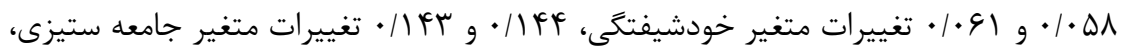

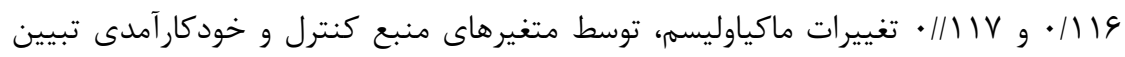

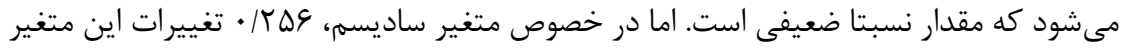

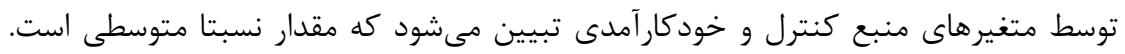

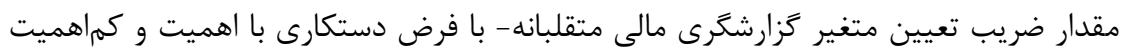

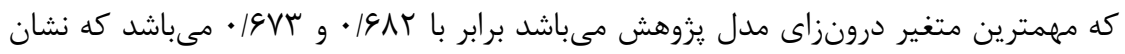

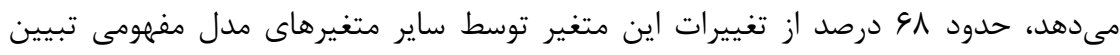

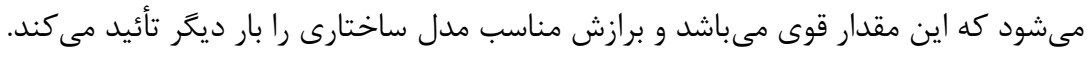

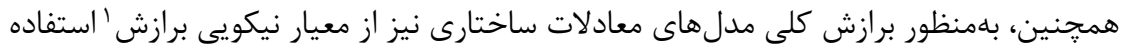

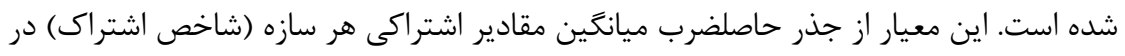

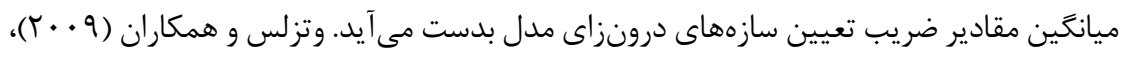

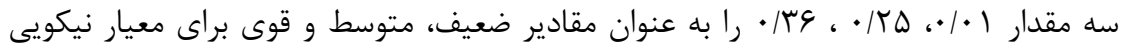

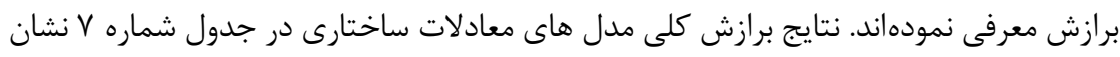
داده شده است.

جدول شمار V. نتايج برازش كلى معادلات ساختارى

\begin{tabular}{|c|c|}
\hline 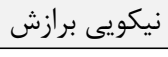 & متغير \\
\hline • rur & مدل اول- كزارشكَى مالى متقلبانه با فرض دستكارى باهميت در سود \\
\hline - kNk & مدل دوم- كزارشكرى مالى متقلبانه با فرض دستكارى كماهميت در سود \\
\hline
\end{tabular}

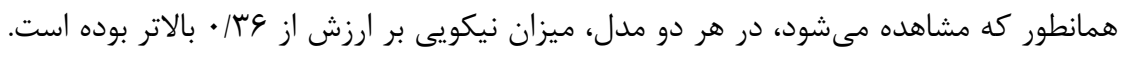

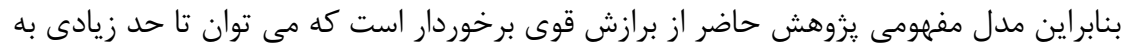

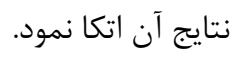

${ }^{1} \mathrm{GOF}$ 
نتايج آزمون فرضيه اول، دوم، سوم و جههارم در نمونه مورد بر برسى نشان داد كه بين متغيرهاى خودكار آمدى و صفات شخصيتى جامعلهستيزى، ماكياوليسم و ساديسم رابطه منفى و معنادارى دارى

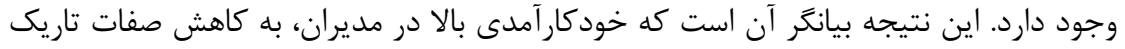

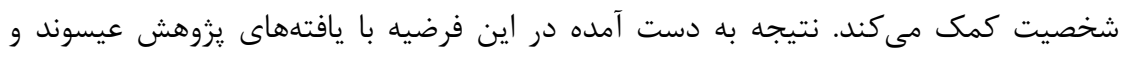

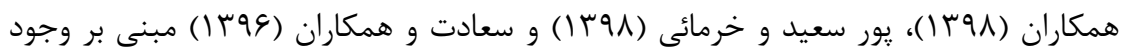

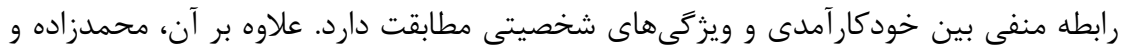

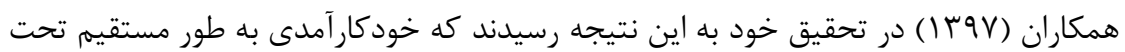

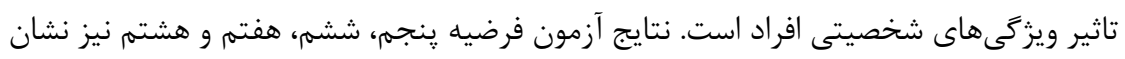
داد كه بين متغير هاى منبع كنترل و صفات شخصيتى خودشيفتكى، ماكياوليسم و ساديسم رابطه

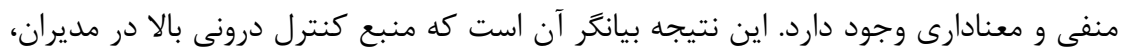

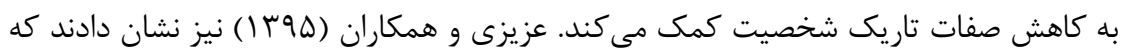

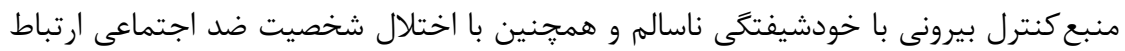

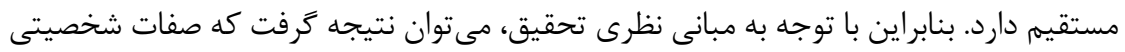

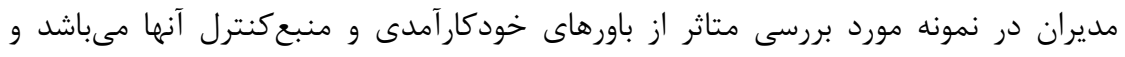

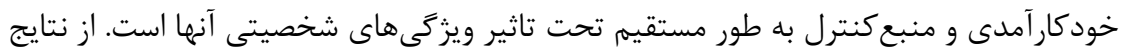
فرضيههاى فوق جنين مىتوان استنباط نمود كه خودكارآمدى با مصاديقى همجون بادئ

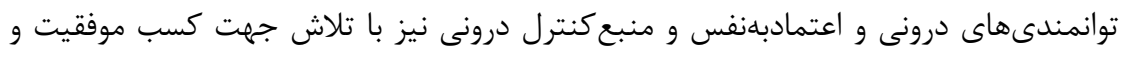
سلامت روان تعريف مىشود و اين نقطه مقابل رفتارهايى است كه در افراد با ويزَّى هاى تانى تاريك شخصيت ديده مىشود. مصداق رفتارهاى ماكياوليستى، جامعهستيزانه و ساديسمى در محيطهاي

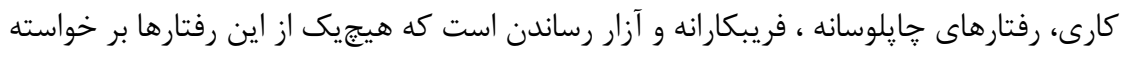

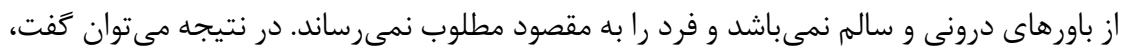

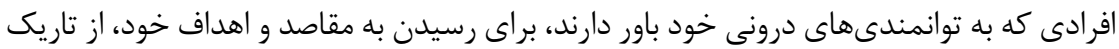

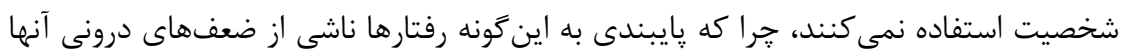

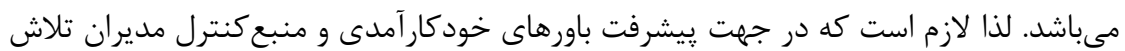

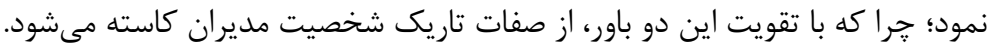

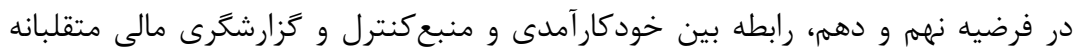

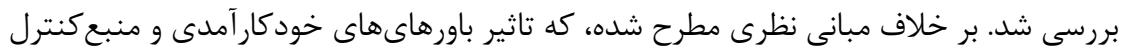

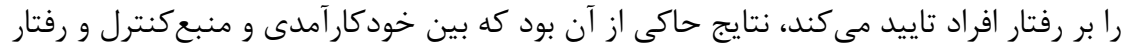

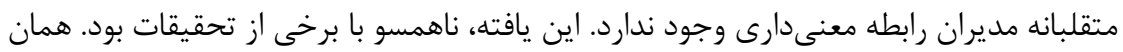




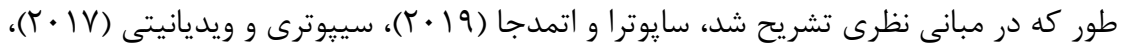

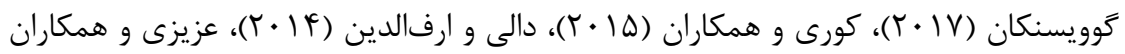

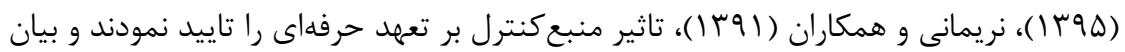

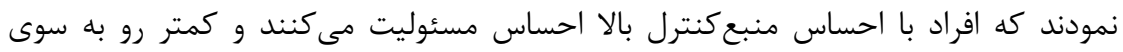

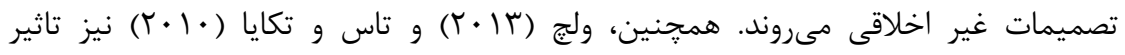

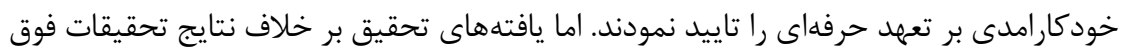

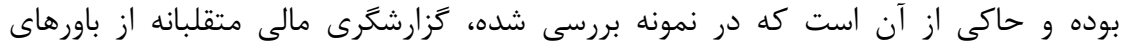

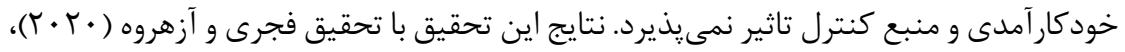

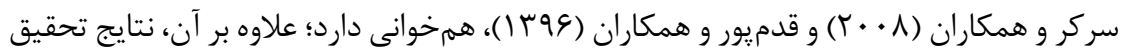

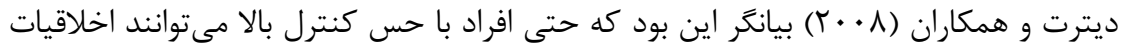

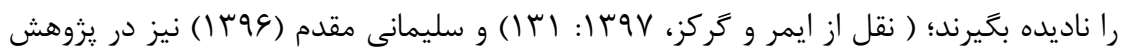

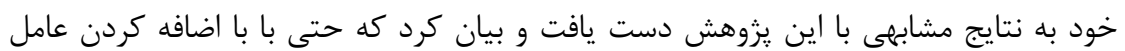
واسطهاى تلاش، بين خودكارآمدى و عملكرد كاركنان رابطه معنى دارى وجود ندارد. با يكسان

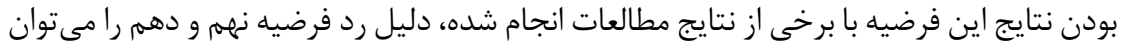

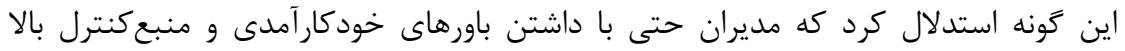

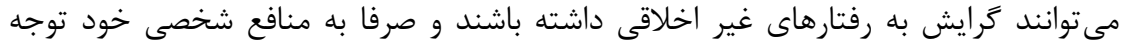
نمايند.

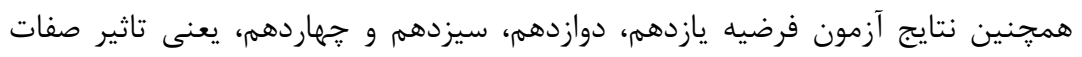

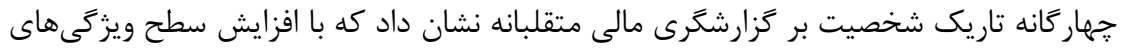

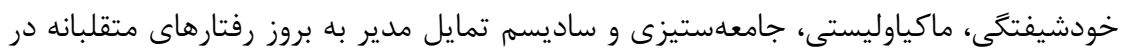

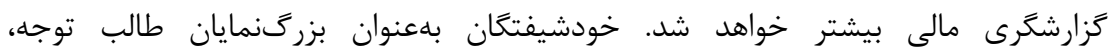

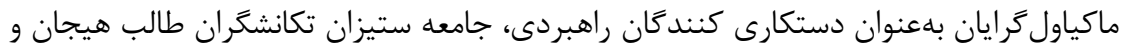

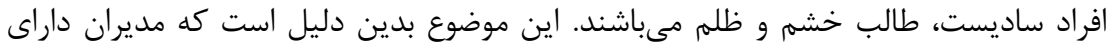

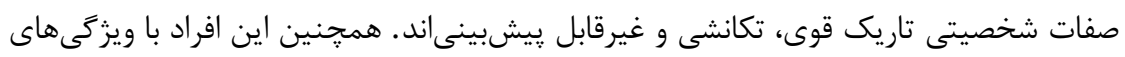

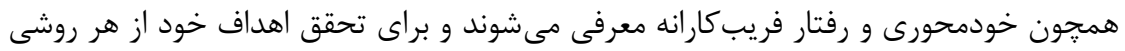

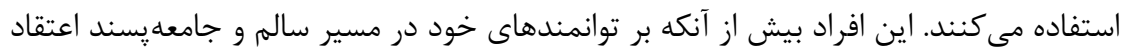

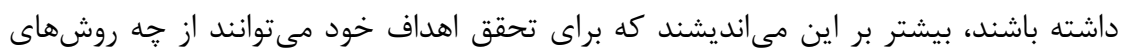

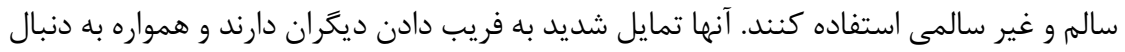

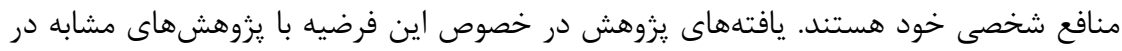

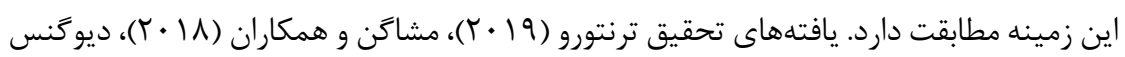




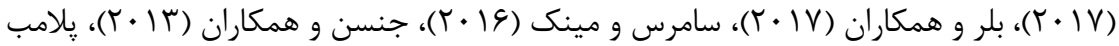

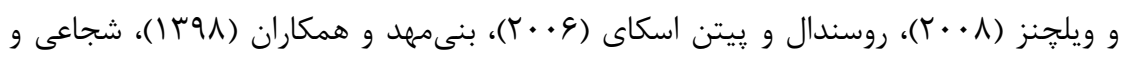

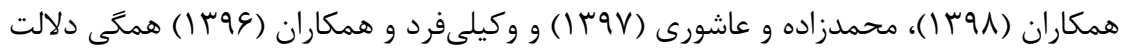

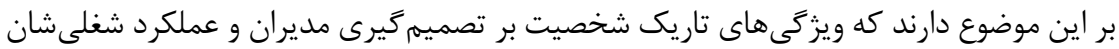

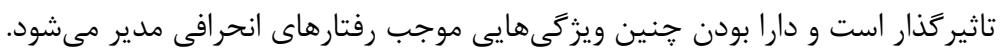

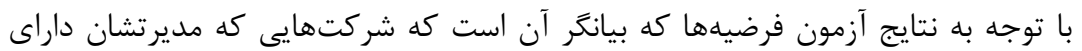

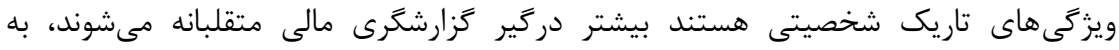

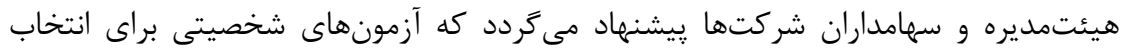

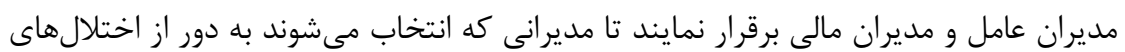

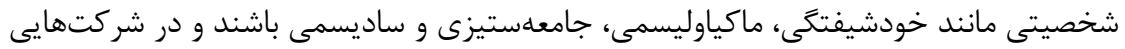

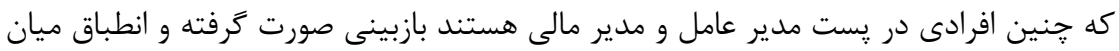

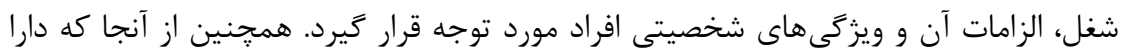
بودن ويزگى هاى تاريك شخصيت بر حسن شهرت مديران اثر سوء دارد، به مدبران شركتها

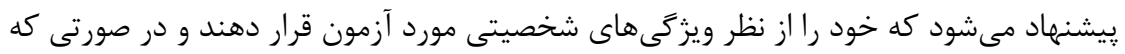

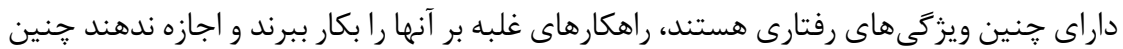

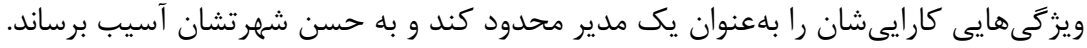

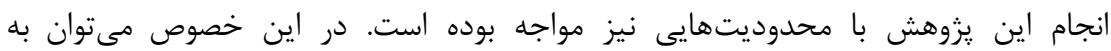

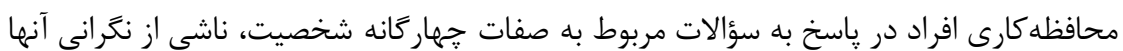
در مشخصشدن اظهارنظر و يا رفتارشان را نام برد.

\section{V - Vقدير، تشكر و ملاحظات اخلاقى}

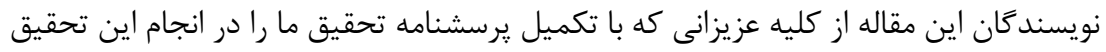

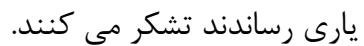

\section{بيوستها: يرسشنامه يزوهش \\ با عرض سلام و احترام}

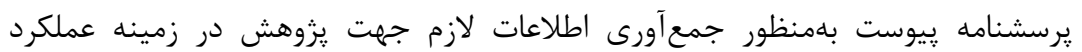
شركتها براى تدوين رساله دكترى در رشته حسابدارى تنظيم كرديده است.

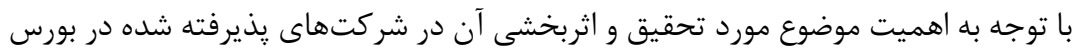

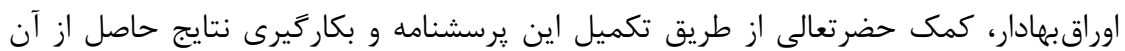


انتظار مىرود موجب رشد و اعتلاى حرفه حسابدارى گردد. لذا خواهشمند است با تامل و با اتكاء

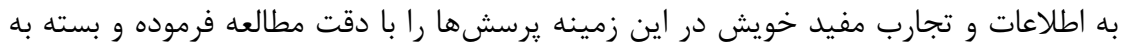

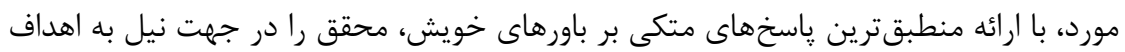

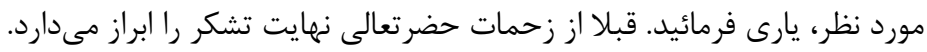

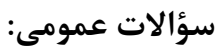

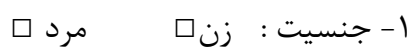

سال

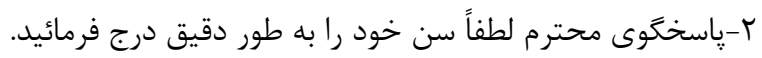

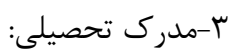
كارشناسى

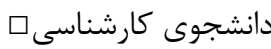

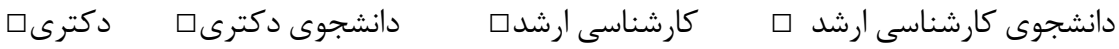

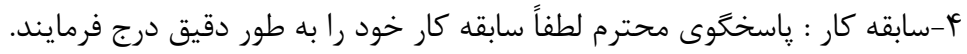
كارشناس حسابدارى ترمايند

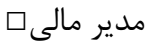

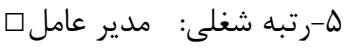

بخش دوم - يرسشنامه دوجين كثيف ( صفات جهار كانه تاريك شخصيت)

\begin{tabular}{|c|c|c|c|c|c|c|}
\hline \multirow[t]{11}{*}{$\begin{array}{l}3 \\
3 \\
3 \\
3\end{array}$} & ?"? & $\begin{array}{l}3 \\
3 \\
3\end{array}$ & $y_{2}$ & $\begin{array}{l}3: \\
y\end{array}$ & 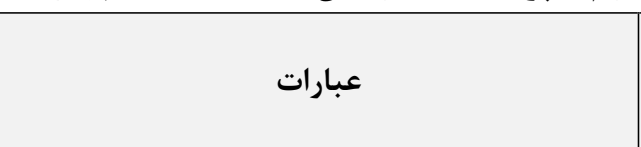 & $\hat{\hat{j}}$ \\
\hline & & & & & |ستفايل دارم براى رسيدن به خواسته هايم از ديخران & 1 \\
\hline & & & & & 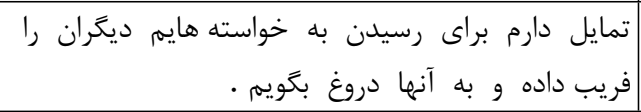 & r \\
\hline & & & & & تعريف و تمارم براى رسيدن به خواسته هايم از ديكران & r \\
\hline & & & & & 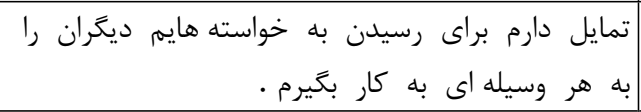 & r \\
\hline & & & & & تمايل دارم احساس يشيمانى نكنم و افسوس نخورم . & $\Delta$ \\
\hline & & & & & تمجه نكنم د • تمارم به جنبه هاى اخلاقى اعمال و رفتارم & 4 \\
\hline & & & & & تمايل دارم تا اندازهاى سنَدل و بى تفاوت باشم . & v \\
\hline & & & & & تمايل دارم نسبت به انسانها بدبين باشم. & $\wedge$ \\
\hline & & & & & تمايل دارم ديكران تحسينم كنند . & 9 \\
\hline & & & & & تمايل دارم ديخران به من توجه كنند . & $1 \cdot$ \\
\hline
\end{tabular}




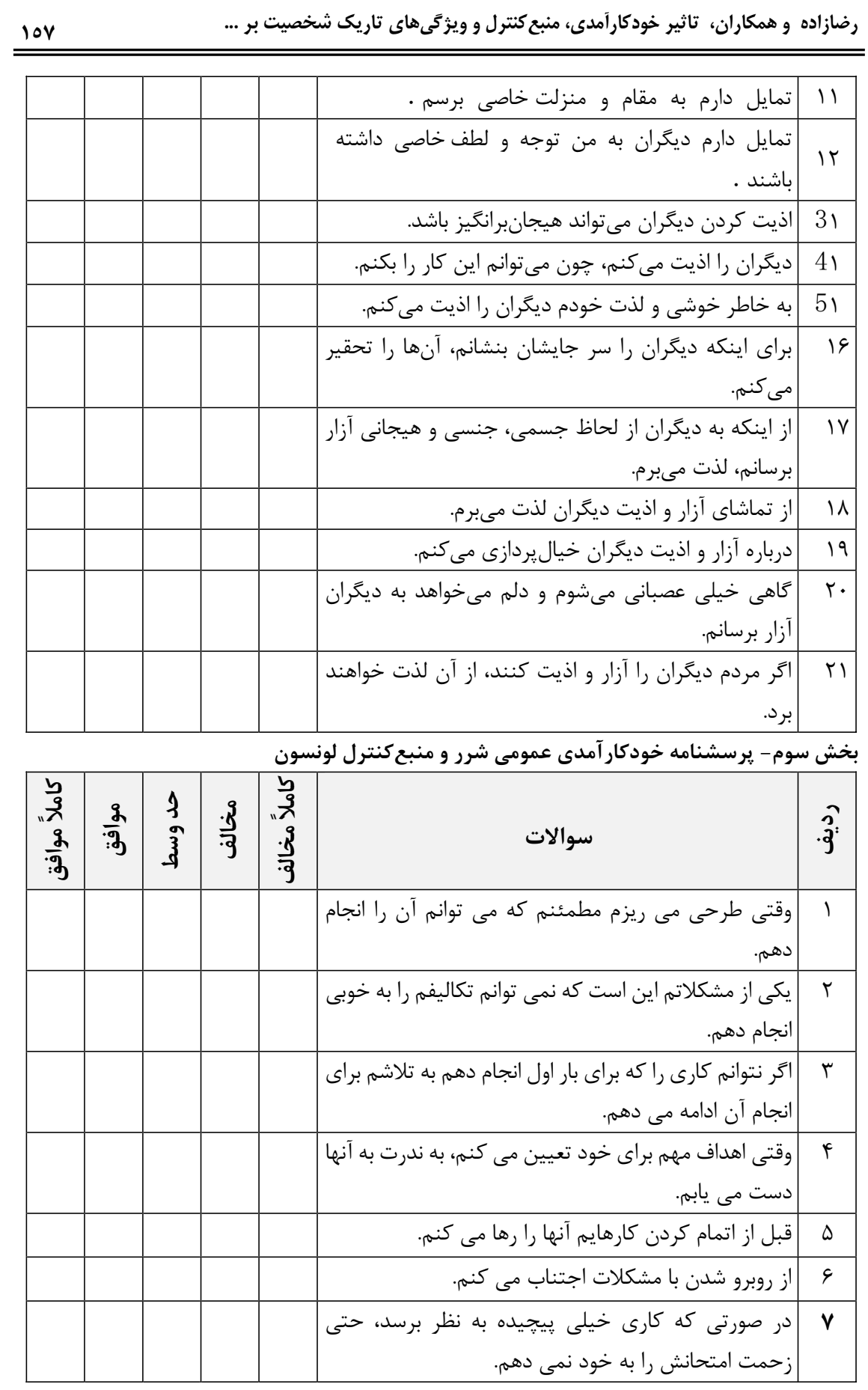


دو فصلنامه حسابدارى ارزشى و رفتارى، سال ينجم، شماره دهم، پِاييز و زمستان وجسا

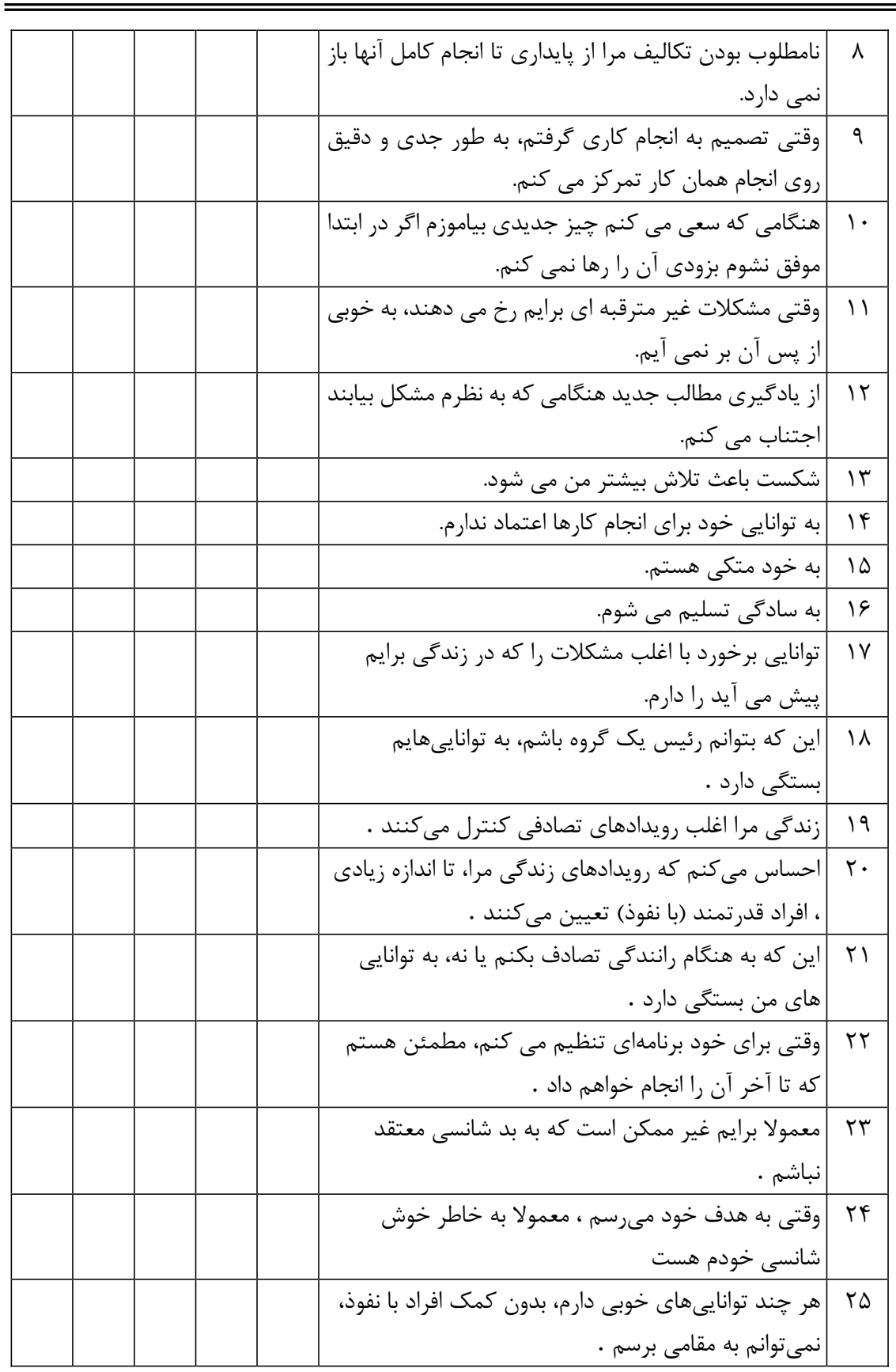




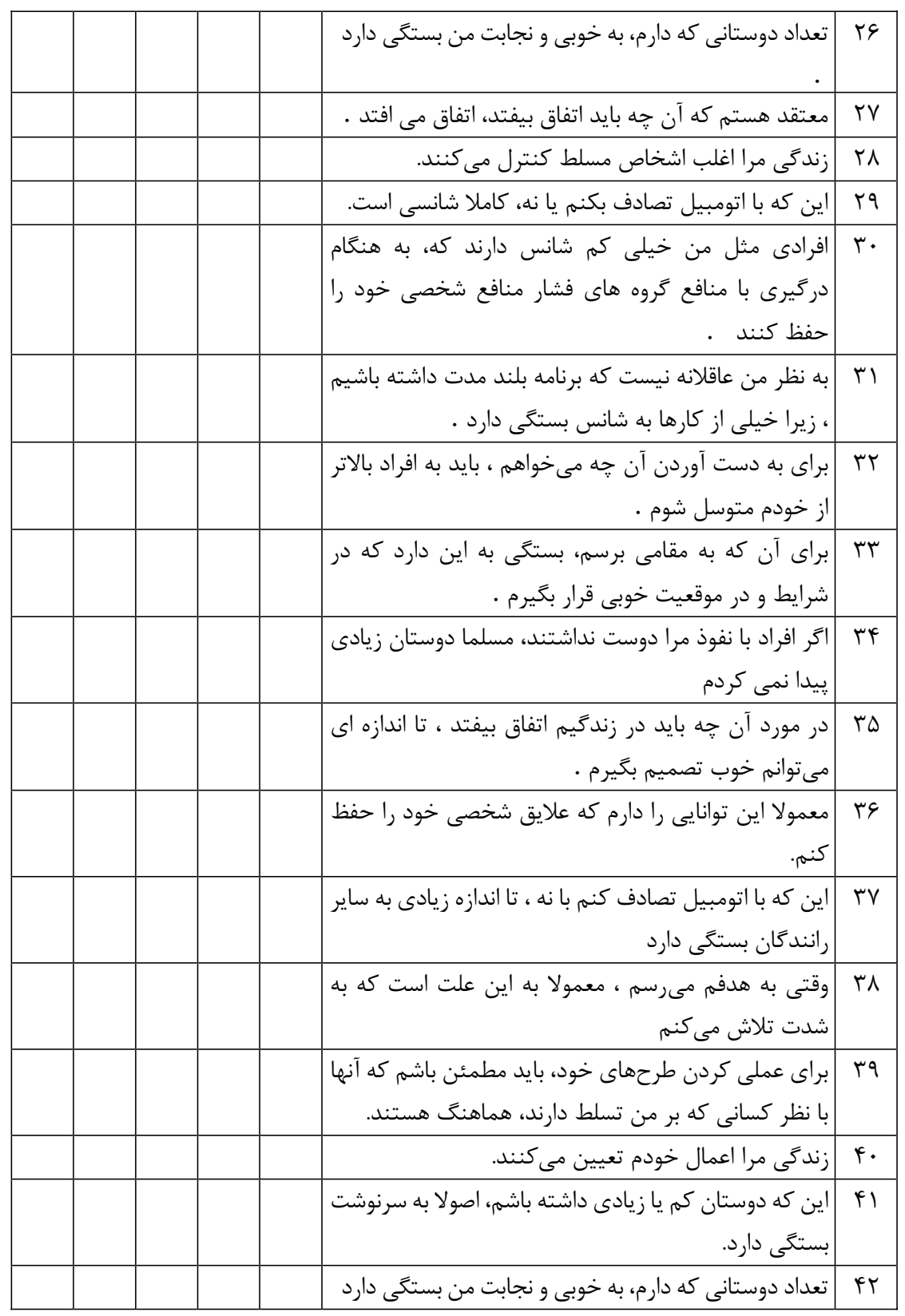




\begin{tabular}{|c|c|c|c|}
\hline \multicolumn{4}{|c|}{ 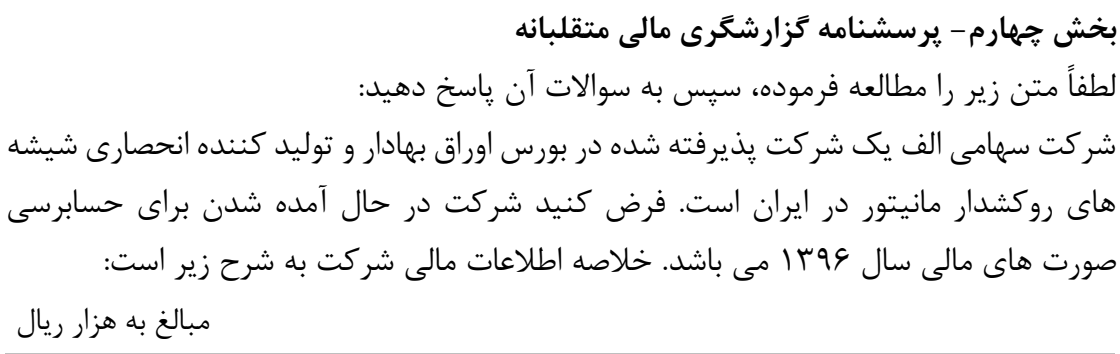 } \\
\hline \multirow[t]{2}{*}{ 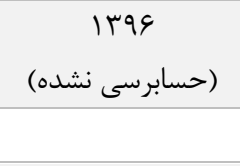 } & $11 \% 90$ & Irqf & \\
\hline & & & ترازنامه: \\
\hline q.• & $\Lambda . r V F . \Delta \Delta q$ & $1 . \Delta 99 . \cdot 1 \cdot$ & دارايى هاى جارى \\
\hline \multirow[t]{2}{*}{ 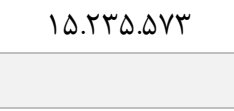 } & A.TqF.Y $\Delta \nabla$ & $\Delta . V V q . \cdot F F$ & 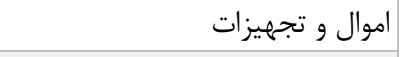 \\
\hline & TET.IV. & ri.VAt & ساير دارايى ها \\
\hline r१.५. ५.१९८ & $|V . \cdot| 1.1 \wedge 9$ & 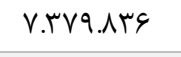 & جمع دارايى \\
\hline $9.11 .4 \cdot 9$ & IT.trT.g19 & r.945.99ץ & بدهى هاى جارى \\
\hline var.rve & q)Q.r.t. & grr.991 & بدهى هاى غير جارى \\
\hline$r 1.191 .9 \cdot 0$ & 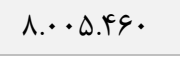 & V.99r.t. & 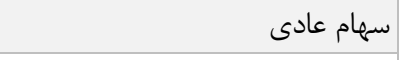 \\
\hline (G.VGT.DTT) & (F.ITY.THT) & $(Y . M$ Y F.YYq) & سود (زيان) انباشته \\
\hline \multirow[t]{2}{*}{ rI.r.r.१९Q } & $|V . \cdot T 1| 19$. & V.rva.^re & جمع بدهى و حقوق صاحبان سهام \\
\hline & & & صورت سود و زيان: \\
\hline$\Lambda . \cdot \& r . \Lambda F \wedge$ & F. rD.rNT & $1.9 \vee .9 \wedge r$ & فروش \\
\hline G.tTt.rTE & T.FOA.TYG & $1 . T 1 \Delta .9 \Delta F$ & بهاى تمام شده فروش \\
\hline $1 . \wedge r 1.0 \cdot r$ & $1 . \Delta \vee V .1 \Delta \varphi$ & $(\mid \backslash \wedge . Y \vee I)$ & سود (زيان) ناخالص \\
\hline f.rVD.DV• & 1.IVT.FTF & $1.4 \wedge 9 . \wedge F$ & هزينه هاى عملياتى \\
\hline$q 4 .+41$ & rFt.VIS & $V F .9 \Lambda \Lambda$ & هزينه مالى \\
\hline$($ ( .9 r $\wedge .1 \cdot 9)$ & $9 \cdot .19$ & $(1.8 \wedge r . \cdot F r)$ & سود (زيان) خالص \\
\hline
\end{tabular}

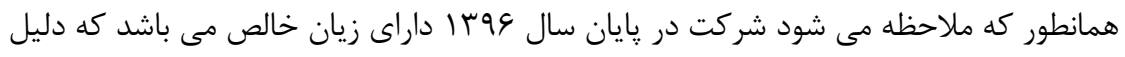

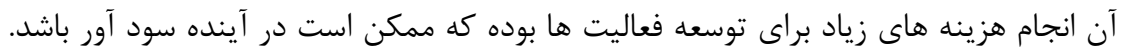

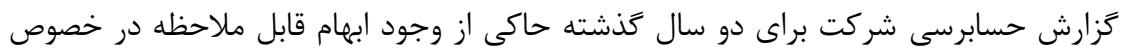

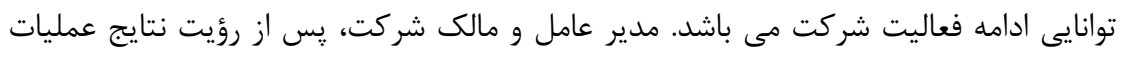

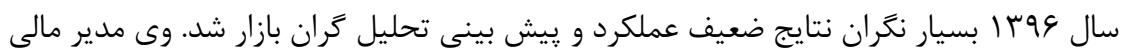




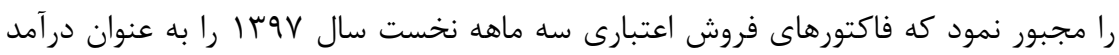

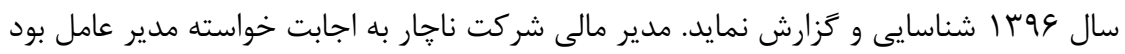

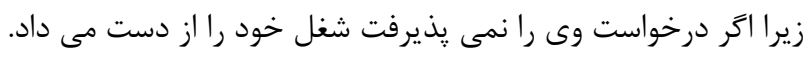
فرض اول (مبالغ دستكارى شده با اهميت باشد):

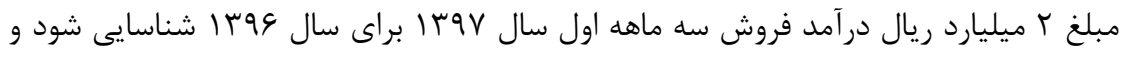

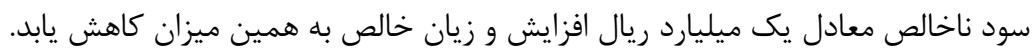
فرض دوم (مبالغ دستكارى شده كم اهميت باشد):

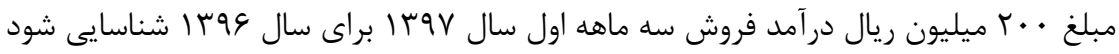

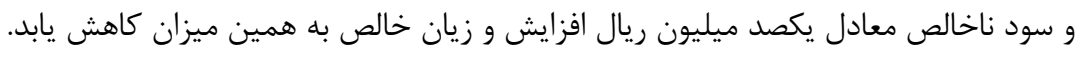

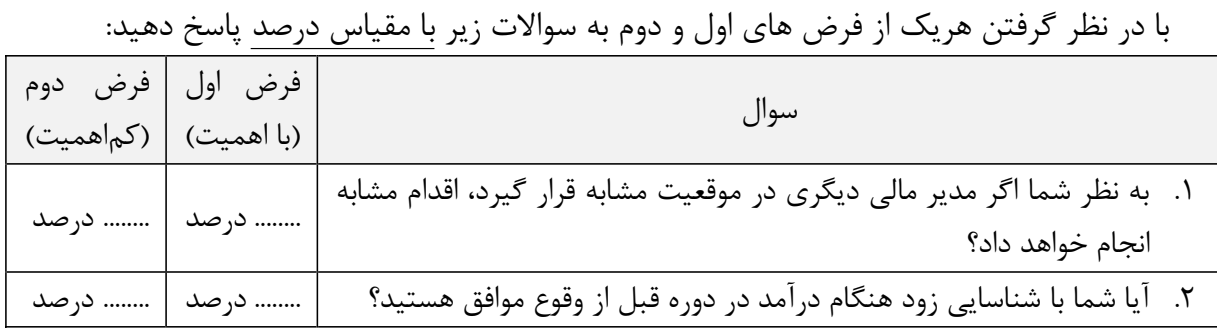

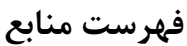

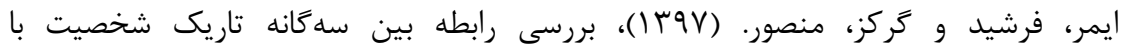

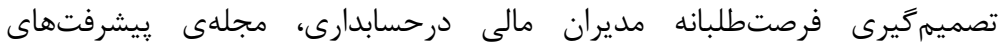

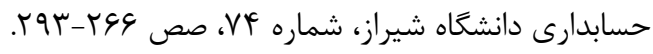

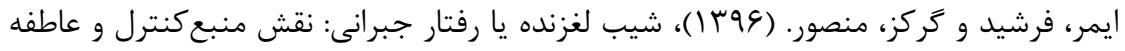

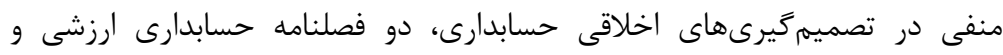

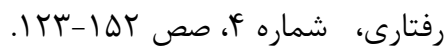

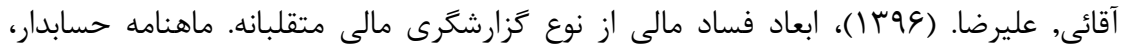

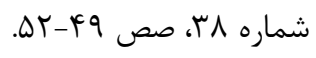

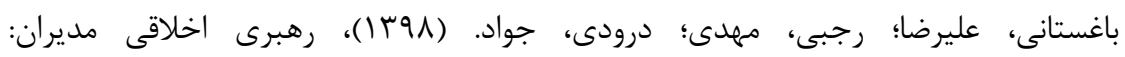

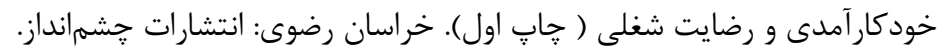

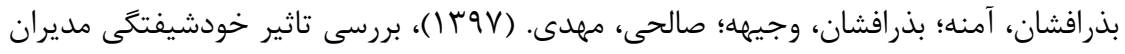

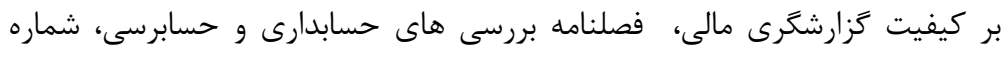

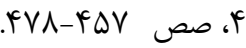




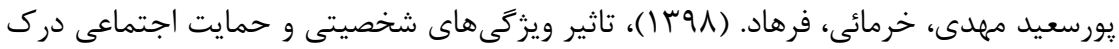

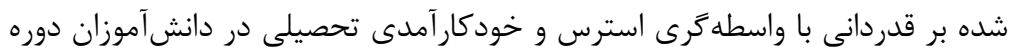

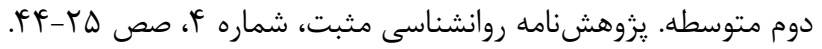

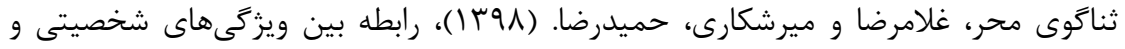

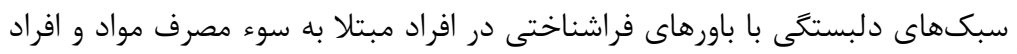

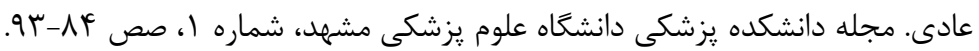

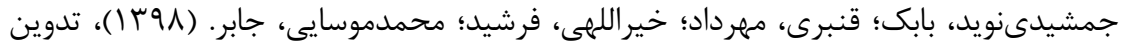

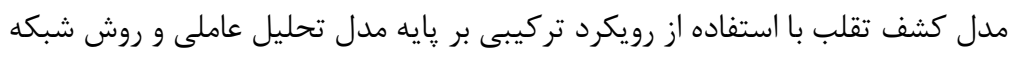

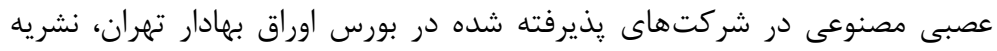

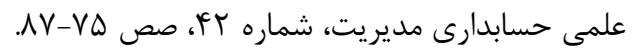

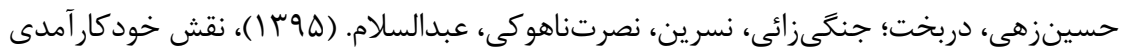

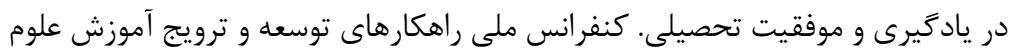

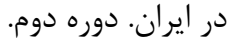

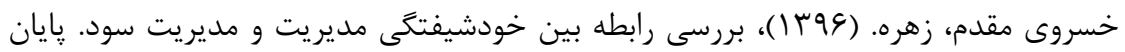
نامه كارشناسى ارشد. دانشخاه الزهرا (س).

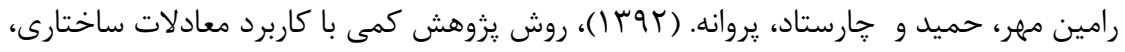
تهران، انتشارات ترمه.

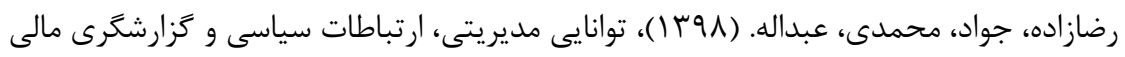

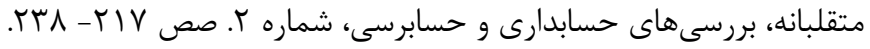

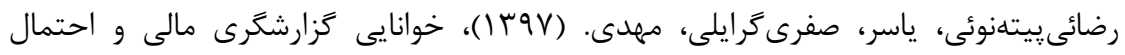

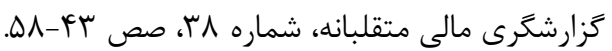

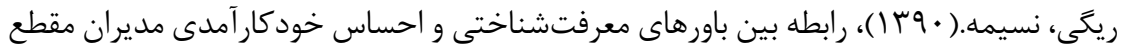
متوسطه. إيان نامه كارشناسى ارشد. دانشخاه سيستان و و بلوجستان.

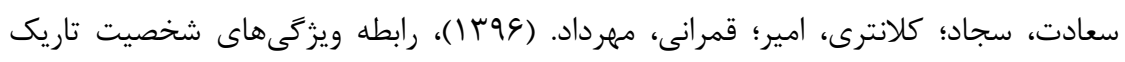

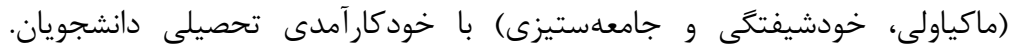

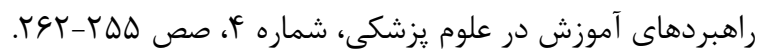

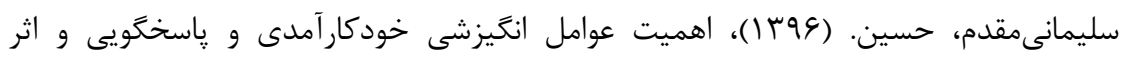

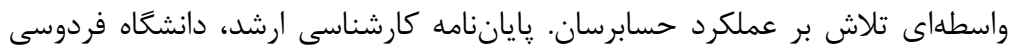


سوادكوهى، رعنا. (991)، اثربخشى آموزش مولفههاى هوشمعنوى بر ارتقاء هوشمعنوى و

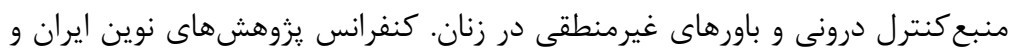

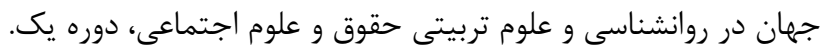

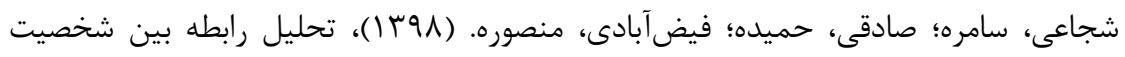

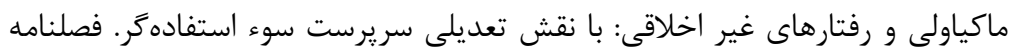

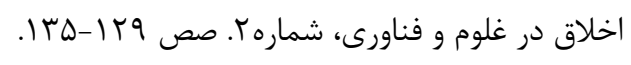

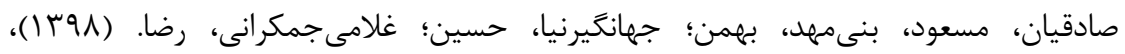

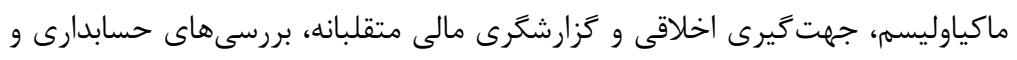

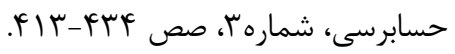

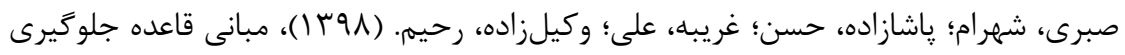

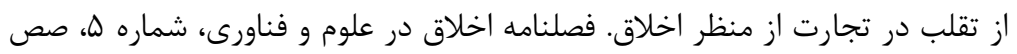

طاووسى، محمد؛ منتظرى، على؛ حيدرنيا، عليرضا؛ طارميان، فرهاد؛ حاجىزاده، ابراهيم؛

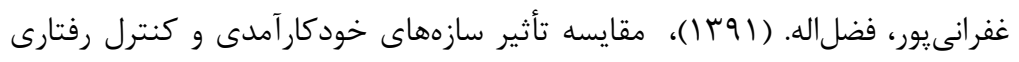

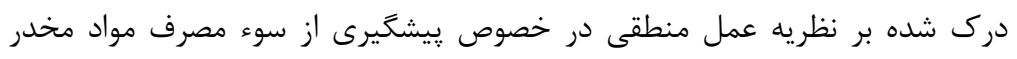

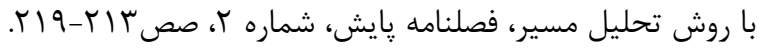

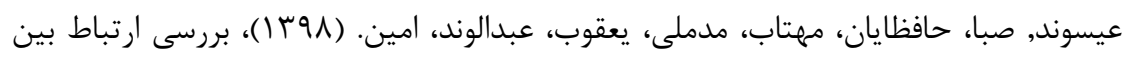

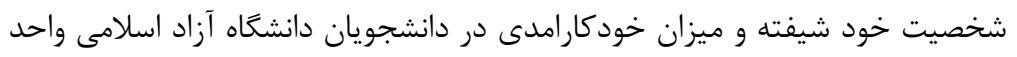

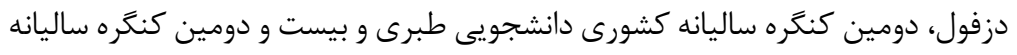

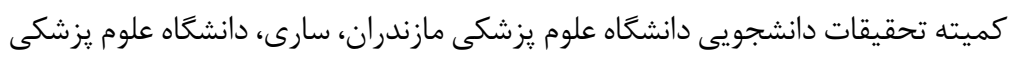
مازندران. عبادى, مريم و نعيمه ماشينجى عباسى.(Y (I))، نقش مولفه كنترل استرس، صفات تاريك

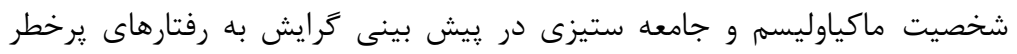

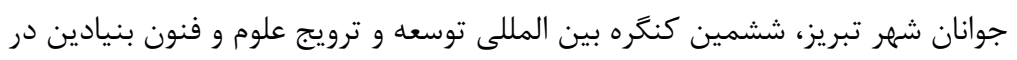
جامعه، تهران، انجمن توسعه و ترويج علوم و فنون بنيادين.

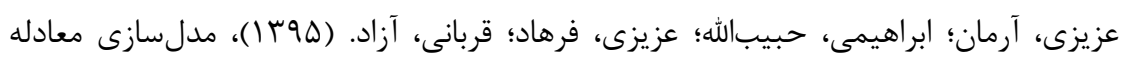

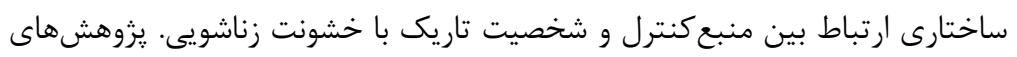

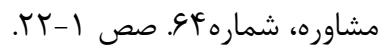




$$
\text { مديريت، حسابدارى و اقتصاد با تاكيد بر بازاريابى منطقه اى و جهانى، تهران - دانشكاه }
$$

$$
\text { شهيد بهشتى، دبيرخانه دائمى كنفرانس. }
$$

Azzahroh, F., and N. Fajri. 2020. The Effect of Self Efficacy and Fraud Diamond on Fraudulent Behavior Academic Accounting Students. Journal of Business, Management, and Accounting 2 (1): 116-122.

Bong, M. 2001. Role of self-efficacy and task-value in predicting college students' course performance and future enrollment intentions. Contemporary Educational Psychology 26(4): 553-570.

Blair, C.A., K. Helland, and B. Walton. 2017. Leaders behaving badly: the relationship between narcissism and unethical leadership. Leadership \& Organization Development Journal 32 (2), 333-346.

Charles, A., and D. Bernadette. 2020. Conceit and deceit: cheating, and stealing among grandiose narcissists. Personality and Individual Differences 154: 1-10.

Charles, A., and D. Bernadette. 2020. The joint of narcissism and psychopathy on accounting students attitudes towards unethical professional practices. Journal of Accounting Education 49: 1-24.

Cohen, J., Y. Ding, C. Lesage, and H .Stoliwy. 2010. Corporate fraud and managers behavior: Evidence from the press. Journal of Business Ethics 95 (2): 271-315.

Cory, N., E. Reeves, and G. Martinez. 2015. Moral Disengagement and Locus of Control in Business School Freshmen: Gender Differences. Southern Journal of Business and Ethics 7: 104-115.

Dali, N., and M .Arifuddin. 2014. The Impact of Professionalism, Locus of Control, and Job Satisfaction on Auditors' Performance: Indonesian Evidence. International Journal of Business and Management Invention , 3(10):63-73.

Diogenes, A. 2017. The dark tetrad of personality and the accounting information quality: The moderating effect of corporate reputation, Ph.D. Thesis, Department of accounting and actuarial sciences, University of Sao Paulo.

Gowrisankar, M. 2017. Role of Locus of Control \& Emotional Quotient Towards Organizational Commitment. International Journal of Management Research and Reviews, 7(1): 28-35.

Hammond., S. 2011. The psychometric properties and utility of the short sadistic impulse scale (SSIS). Psychological Assessment 23 (2):523-531.

Harrison., A. and B. Mennecke. 2016. The Effect of the Dark Triad on Unethical Behavior. Journal of Business Ethics, 153 (2): 1-25. 
Jaffé. M., R. Greifeneder, and M. Reinhard. 2019. Manipulating the odds: The effects of Machiavellianism and construal level on cheating behavior. PLOS ONE. 14(11): 1-22.

Johnson, W., W, Xie, and S. Yi. 2014. Corporate fraud and the value of reputations in the product market. Journal of Corporate Finance, 25:16-39.

Jessica, R. N. Daniel, and M. Steven. 2020. Perceiving opportunities for legal and profit: Machiavellianism the Dark Triad. Personality and Individual Differences 162: 1-4.

Jonason, P.,and G. Webster. 2020. The dirfy dozen: A concise measure of the dark triad. Psychological Assessment. 2010; 22(2):420-32. Kontesa, M., Brahmana., R., Tong, A. Narcissistic CEOs and their earnings management. Journal of Management and Governance. 24 (1): $1-27$.

Jones., D.N. 2016. The nature of Machiavellianism: Distinct patterns of misbehavior. In V.ZeiglerHill \& D.K. Marcus (Eds), the dark ide of personality. American Psychological Association.

Joshua, C., R. Palmer, J. Holmes, and L. Pamela. 2020. The Cascading Effects of CEO Dark Triad Personality on Subordinate Behavior and Firm Performance: A Multilevel Theoretical Model, Group \& Organization Management. 45 (1):1-38.

Lee, S., Su. Jau-Ming, T. Sang-Bing, Lu. Tzu-Li, and W. Dong. 2016. A comprehensive survey of government auditors' self-efficacy and professional development for improving audit quality. Springer Plus. $5(1): 1-25$.

Levenson. H. 1973. Multidimensional locus of control in psychiatric patients. Journal of Consulting and Clinical Psychology,41(3):397 404.

Majors, T.M. 2015. The interaction of communicating measurement uncertainty and the dark triad on managers, reporting decisions. The Accounting Review, 91 (3): 973-992.

Moshagen, M., B. Hilbig, and I. Zettler. 2018. The dark core of personality. Psychological Review, 125 (5): 656-688.

Murphy, P. 2012. Attitude, Machiavellianism and the rationalization of misreporting, Accounting Organizations and Society . 37 (4): 242 259.

Olsen, K., and J. Stekelberg. 2015. CEO narcissism and corporate tax sheltering. The Journal of the American Taxation Association,38 (1): $1-22$

OMeara, A., J. Davies, and S. Hammond. 2011. The psychometric properties and utility of the short sadistic impulse scale (SSIS). Psychological Assessment. 23 (2): 523-531. 
Respati, t. 2011. The Influence of Locus of Control on the Relationship of Manager's Attitudes, Subjective Norms, Perceived Behavior Control, and Manager's Intention in Committing Fraud on the

Presentation of Financial Statements, Journal of Accounting and

Finance in Indonesia. 8: 123-140.

Rijsenbilt, A., and H. Commandeur. 2013. Narcissus Enters the Courtroom: CEO Narcissism and Fraud. Journal of Business Ethics, 117(2). 413429.

Sarker, S., S. Barnes, and R. Reed. 2008. Managerial Ethics, Performance

Pressure and Governance: The Case of Misleading Financial Disclosures. Academy of Management Annual Meeting Proceedings. Anaheim, CA.

Sherer,' M., J. Maddux, B. Mercadante, S. Prentice-Dunn,. B. Jacobs, and R. Rogers. 1982. The Self-efficacy Scale: Construction and validation. Psychological Reports, 51 (2): 663-671.

Southard, A., A. Nose, N. Pollock, S. Mercer, and V. Zeigler- Hill. 2015.

The interpersonal nature of dark personalities features. Journal of Social and Clinical Psychology, 34 (7): 555-586.

Triantoro, H., I. Utami, and C, Joseph. 2019. Whistleblowing system, Machiavellian personality, fraud intention: An experimental study Journal of Financial Crime, 27 (1): 202- 216.

Wen, Z., H. Gu, and X. Fan. 2017. Structural validity of the Machiavellian Personality Scale: A bifactor exploratory structural equation modeling approach. Personality and Individual Differences, 105: 116123.

Welch, J., 2013. The Importance of Self-Efficacy in Ethics Education for Business Undergraduates, Southern Journal of Business \& Ethics. 5:214-223.

Widiyanti, A., and M. Sayputri. 2019. Effect of Budget Participation on Managerial Performance with Organizational Committees and Locus of Control as Moderating Variables. Journal of Accounting and Finance, 22:136- 146 .

Zeigler- Hill,V., and D. Marcus. 2016. The dark side of personality: science and practice in social, personality, and psychology. Washington: American Psychological Association, 389. 